\title{
Anthropometry of Newborn Infants Born in 14 Teaching Centers in Indonesia
}

\author{
Anna Alisjahbana, Alex Chaerulfatah, Ali Usman, Sri Sutresnawati
}

\begin{abstract}
Anstract Percentile curves representing intrauterine growth of Indonesian infants ranging from 34 to 43 weeks of gestation in 14 teaching centers were constructed from birth weight, birth length, and head, mid-upper arm, and chest circumferences. The gestational age was determined based on the last menstrual period. Mothers with probable chronic diseases or pregnancy complications were excluded. Included for analysis were 5844 singleton newborns. The mean birth weight of Indonesian babies was higher for gestational age of 34-38 weeks, but lower at 40-42 weeks of gestation compared with that of the Denver study. The results showed that the mean birth weight of Denver's newborns was significantly different than that of the Indonesian infants, therefore the Denver intrauterine growth curve cannot be used as reference curve for Indonesian newborns. Baby boys in general had a higher mean birth weight, birth length, head circumference, and chest circumference. No difference was found for arm circumference. For every gestational age and percentiles, later born infants were heavier than first born infants. Birth weight at 42 weeks was lower for first born infants, this was not shown in later-born infants which showed higher weight for each percentiles. Parity affected birth weight more than birth length. Birth length became more stable at 39 weeks. Chest circumference of $<29 \mathrm{~cm}$ had the highest sensitivity and positive predictive value for low birth weight, followed by arm circumference of $<9 \mathrm{~cm}$. The use of infrauterine growth chart in studying the nutritional status of babies at birth was described. [Paediatr Indones $1994 ; 34: 62-123$ ]
\end{abstract}

\section{Introduction}

Norms, definition, and classification form the foundations on which all scientific endeavor must be built, and yet we still have not achieved agreement on many

Accepted for publication: March 23, 1994. For correspondence: Anna Alisyahbana, MD, PhD, Department of Child Health, Padjadjaran University, Jalan Pasteur no. 38, Bandung, Indonesia. medical aspects, including growth in the perinatal period. In November 1984, a multidisciplinary international workshop was held in Cairo to discuss the methodology of measuring and recording infant growth in the perinatal period.

Until recently researchers and program implementators in Indonesia have been using the intrauterine growth curve from Denver ${ }^{1}$ as the reference curve for 


\section{ABBREVIATIONS USED IN THIS REPORT}

$\begin{array}{ll}\text { GA } & =\text { gestational age } \\ \text { BW } & =\text { birth weight } \\ \text { BL } & =\text { birth length } \\ \text { HC } & =\text { head circumference } \\ \text { CC } & =\text { chest circumference } \\ \text { LMP } & =\text { last menstrual period } \\ \text { LBW } & =\text { low birth weight } \\ \text { AC } & =\text { arm circumference } \\ \text { AC/HC } & =\text { arm / head circumference ratio } \\ \text { Unsyiah } & =\text { Syah Kuala University, Aceh } \\ \text { USU } & =\text { University of Sumatra Utara, Medan } \\ \text { Unand } & =\text { Andalas University, Padang } \\ \text { Unsri } & =\text { Sriwidjaja University, Palembang } \\ \text { Unsrat } & =\text { Sam Ratulangi University, Manado } \\ \text { Unhas } & =\text { Hasanudin University, Ujung Pandang } \\ \text { Unair } & =\text { Airlangga University, Surabaya } \\ \text { Unbraw } & =\text { Brawidjaja University, Malang } \\ \text { UGM } & =\text { Gadjah Mada University, Yogyakarta } \\ \text { Undip } & =\text { Diponegoro University, Semarang } \\ \text { UNS } & =\text { Sebelas Maret University, Solo } \\ \text { UI } & =\text { University of Indonesia, Jakarta } \\ \text { Unpad } & =\text { Padjadjaran University, Bandung } \\ \text { RSHK } & =\text { Mother and Child Hospital Harapan Kita, Jakarta }\end{array}$

Indonesian newborns, because no national data were available. Developing an intrauterine growth curve is handicapped by the difficulty in collecting data on gestational age in Indonesian women. Previous survey has shown that less than $20 \%$ of women delivering in the general hospitals knew the exact date of the last menstrual period. For women in rural areas it is even worse, because they are not familiar with calculating the ex- pected date of birth using the first date of the last menstrual period.

Birth weight and length of babies are closely related to race and the physical measurements of mothers; some authors also mention a difference of birth weight in relation to ethnic group. For those reasons, several authors recommend that each country should have its own intrauterine growth curves. However many researchers mention a better 
relation between birth weight and length with the nutritional status of the women rather than with ethnic groups. Therefore it is still debatable whether a national standard intrauterine growth curve should be used for all Indonesian newborns, considering the difference in ethnic groups and nutritional status of women in urban and rural areas.

It is well known that birth weight is a good indicator for the health and nutritional status of a community. ${ }^{2}$ Birth weight has long been a subject of clinical and epidemiological investigations, and a target for public health interventions. Considerable efforts have been focussed on the determinants of birth weight, especially of low birth weight. The WHO reports on the use of simple anthropometric measurement for predicting birth weight conducted in 22 centers throughout the world not including Indonesia, recommend that chest rather than arm circumference should be used as a surrogate for birth weight. ${ }^{3}$ It means that if a reliable measuring instrument for weighing infants is not available, then chest circumference can be used to replace birth weight. Unless an appropriate study is conducted in Indonesia on birth weight and birth weight surrogates, the WHO recommendation should be applicable; the question is only whether the cut-off points for both measurements are the same as for other developing countries. There is a need for a large population of mothers and infants surveyed in order to have enough subjects which would permit analyses of anthropometric measurements for the purpose of a national reference curve for Indonesian newborns.

\section{Aims of the present study}

The specific aims of this study were:

1. To present anthropometric data on newborn infants who were free from all known factors influencing intrauterine growth retardation. This was obtained by examining the infants at birth and by reveiwing their mother's medical and obstetric records.

2. To collect information on five different anthropometric measurements of live born infants, e.g., birth weight, birth length, head circumference, chest circumference, and mid upper arm circumference, and to develop standard intrauterine growth curves based on those measurements.

3. To compare five anthropometric measurements with respect to their correlation to gestational age.

4. To present confidence limits for estimating gestational age from anthropometric measurement of the infants

5. To identify a suitable surrogate for birth weight that correlates well with birth weight, to enable to identify low birth weight baby accurately and easily using a simple instrument.

\section{Definitions}

Mean was defined as average of values. Standard deviation was the distribution on either side of the mean that encompassed $66.7 \%$ of the observations (mean \pm 2 SD encompassed $95 \%$ of the observations). Median was defined as the middle observation in a group. Percentile was defined as a value in a series of observations when the series was defined into 100 groups of equal frequency; asinto rank thus indicated signment of given was greater than the that the value given was greater than for the specified percentage of the values for the entire group. Gestational age referred to entire group. from the first day of the age in weeks from the period until the mother's last menstrual peight referred to day of birth. Low birth wes than 2500 grams a birth weight of luded), irrespective of the gestational age.

\section{Methods}

The study was undertaken in 14 teaching hostals in Indonesia (see Table 1). ing hospitals in indo the contributors of These centers were the conter were the survey. Data from each center were

collected according to a detailed protc
so as to ensure their comparability.

\section{Criteria for inclusion}

Only infants whose mothers had a reliable information about gestational age were included in the study. The mothers were interviewed by the investigator at each center soon after delivery. All records of the prenatal visits were checked. The following criteria had to be fulfilled for inclusion; these have been suggested by Finstrom ${ }^{4}$ and Miller. ${ }^{5}$

1. At interview the mother could state the exact date of the beginning of her last menstrual period (LMP). This date should have been the same as that earlier given at the first antenatal visit;

2. The menstrual cycles had been regular at intervals of $28 \pm 3$ days before pregnancy;
The LMP should have been normal with respect to duration and amount, and occurred on the expected date;

4. If oral contraceptives had been used, at least one spontaneous menstruation should have occurred before pregnancy;

5. There should have been no bleeding during the first 2 months after the last LMP;

6. The time elapsed from the LMP to the recognition of fetal movement should have been within the following limits; for primipara, fetal movements not earlier than 18th week and not later earlier than 18th week and not not earlier than the 16th week and not later than the 20th week;

7. Abnormal factors influencing fetal growth (e.g., fetal abnormalities or medical complications of pregnancy) were to be excluded.

\section{Procedures}

A midwive weighed the infant immediately after birth on a balance scale ately after birth on a balance scale ized weight as part of routine care). The recorded to weight was registered and birth length or the nearest length was measured using a crown-heel length was morts for the head and feet. The length, head circumference, mid upper arm circumference, and chest circumference were recorded using a measuring tape and recorded to the nearest $\mathrm{mm}$. The measurements of arm and chest circumferences were done arm and che instructions outlined in the section on "Instruction for completing the questionnaire" of the WHO study 
protocol for birth weight surrogates. ${ }^{6}$ All measurements were recorded within one to three hours after birth. In addition, sex and gestational age at birth were also recorded. The main problem with respect to data quality was that of digital preference. There was a strong tendency for measurements to be recorded in round hundred grams or whole centimeters.

\section{The Study Subjects}

The study involved 6110 infants of various gestational ages, admitted to $14 \mathrm{se}$ lected teaching hospital during one year period from July 1,1990 to June 30, 1991. Gestational age, sex, and ethnic group were recorded, and anthropometric measurements on birth weight, birth length, and chest, upper arm, and head circumferences were performed. The number of infants who had reliable information on gestational age is depicted in Table 1. Of the 6110,36 forms were not completed, and 6074 had all the information required. From those, there were 5884 singletons and 190 twins. For the purpose of this report only singleton infants were included. Outliers were excluded, and after readjustment, 5844 infants were left for analyses.

\section{Results}

\section{Anthropometric Measurements}

Some basic factors have to be considered in evaluating fetal growth in a normal uncomplicated pregnancy, these include race, age, parity, weight, and habitus
Table 1. Teaching centers and number of infants
studied studied

\begin{tabular}{rlr}
\hline No & \multicolumn{1}{c}{ Teaching hospital } & $\begin{array}{r}\text { No of } \\
\text { infants }\end{array}$ \\
\hline 1 & Unsyiah & 727 \\
2 & USU & 246 \\
3 & Unand & 96 \\
4 & Unsri & 503 \\
5 & Unsrat & 402 \\
6 & Unhas & 394 \\
7 & Unair & 293 \\
8 & Unbraw & 280 \\
9 & UGM & 662 \\
10 & Undip & 678 \\
11 & Uns & 192 \\
12 & UI & 386 \\
13 & Unpad & 560 \\
14 & RSHK & 425 \\
\hline & Total & 5,844 \\
\hline & &
\end{tabular}

(weight for length) of the mother and the sex and gestational age of the fetus. These factors might affect crown heel length, head size, and weight of the fetus in different degrees, depending on the factor and parameter involved. These factors taken together would appear to make the evaluation of fetal growth a complex matter. The primary objectives of collecting anthropometric data were to determine whether the newborn infant was underweight, normal, or overweight for height, and if the individual is short, medium, or tall for her gestational age.

About $85 \%$ of all infants born during the period of observation were excluded because of unknown gestational age or growth-retarding factors. No full term dying in the perinatal period was included. Data on birth weight, birth length, head circumference, and mid upper arm circumference were grouped according to sex and percentiles at successive weeks of gestation. Values for the 10th, 25th, 50 th, 75th, and 90th percentiles were read from the curves. The resulting figures were graphed at the mid-point of the proper week and smoothed arithmatically. ${ }^{1}$

The mean and standard deviation of anthropometric measurements of all infants studied are depicted in Table 2 . Mean birth weight and length for boys were on the average higher compared with those for girls. Baby boys were almost $60 \mathrm{~g}$ heavier than girls; the difference was significant $(\mathrm{p}<0.001)$; baby boys were $0.5 \mathrm{~cm}$ longer than girls, this difference was not significant. The difference for head circumference was $0.3 \mathrm{~cm}$ higher for boys. The differences for mid upper arm circumference and chest circumference were smaller. The chest circumference of boys was $0.2 \mathrm{~cm}$ and significantly larger than that of girls $(p<0.002)$. No difference was found for arm circumference of boys who was 0.1 $\mathrm{cm}$ larger than that of girls $(\mathrm{p}=0.69)$.

\section{Birth weight}

The weight at birth of the infant is one of the most fundamental measurements, and its technique of measurements is less prone to observer error than any other measurements. Birth weight is a useful indicator for neonatal survival, and is affected by gestational age and gender of the infant and maternal age and parity.

Birth weight for boys and girls in percentiles in this series can be seen in $\mathrm{Ta}$ bles III, IV, and V and the growth curves are shown in Figures 1, 2, and 3 of the Annex. Baby boys were on the average heavier than baby girls; the difference was consistent for any value of each percentiles although some variations were found. A comparison was made for first born and later-born infants for full term infants and sex combined. For every gestational age and percentiles, laterborn infants were heavier than first-born infants (Table 3). Birth weight at 42 weeks gestation was lower in first-born infants, this was not shown in the laterborn infants which showed higher weight at each percentile.

\section{Birth length}

Birth length or crown-heel length is a measure for linear growth. The same result as for birth weight can be seen for birth length, i.e., boys were longer than girls. The mean difference between both sexes was $0.5 \mathrm{~cm}$, or baby girls are about 1 percent shorter than boys. A difference in length was found at each percentile of the growth curve (see Annex, Tables VI, VII, and VIII, and Figures 4, 5 and 6). After 39 weeks of gestation the growth curve showed a straight line while for infants of more than 44 weeks of gestation the growth curve declines, probably due 
Table 2. Mean and standard deviation of anthropometric measurements of newborns infants at 14 teaching centers in Indonesia (singletons only).

\begin{tabular}{lcccccc}
\hline & No of infants & $\begin{array}{c}\text { BW, gram } \\
(\mathrm{SD})\end{array}$ & $\begin{array}{c}\mathrm{BL}, \mathrm{cm} \\
(\mathrm{SD})\end{array}$ & $\begin{array}{c}\mathrm{HC}, \mathrm{cm} \\
(\mathrm{SD})\end{array}$ & $\begin{array}{c}\mathrm{AC}, \mathrm{cm} \\
(\mathrm{SD})\end{array}$ & $\begin{array}{c}\mathrm{CC}, \mathrm{cm} \\
(\mathrm{SD})\end{array}$ \\
\hline Total & \multirow{2}{*}{5844} & 3085 & 49.1 & 33.5 & 10.9 & 32.5 \\
& & $(444)$ & $(2.1)$ & $(1.8)$ & $(1.3)$ & $(2.1)$ \\
\multirow{2}{*}{ Male } & \multirow{2}{*}{3052} & 3118 & 49.4 & 33.6 & 10.9 & 32.5 \\
& & $(449)$ & $(2.1)$ & $(1.8)$ & $(1.3)$ & $(2.2)$ \\
\multirow{2}{*}{ Female } & \multirow{2}{*}{2792} & 3049 & 48.9 & 33.3 & 10.8 & 32.4 \\
& & $(437)$ & $(2.0)$ & $(1.8)$ & $(1.2)$ & $(2.0)$ \\
\hline
\end{tabular}

Table 3. Percentile distribution of birth weight $(g)$ of firstborn and later-born full term infants (sex combined)

\begin{tabular}{|c|c|c|c|c|c|c|c|c|c|c|c|c|}
\hline \multicolumn{13}{|c|}{ Gestational age (weeks) } \\
\hline \multirow[t]{2}{*}{ Percentile } & \multicolumn{6}{|c|}{ First born } & \multicolumn{6}{|c|}{ Later bọm } \\
\hline & 37 & 38 & 39 & 40 & 41 & 42 & 37 & 38 & 39 & 40 & 41 & 42 \\
\hline 90 & 3259 & 3294 & 3460 & 3510 & 3645 & 3600 & 3405 & 3450 & 3600 & 3750 & 3850 & 3896 \\
\hline 75 & 3000 & 3070 & 3241 & 3250 & 3370 & 3315 & 3190 & 3200 & 3350 & 3500 & 3500 & 3600 \\
\hline 50 & 2700 & 2890 & 2970 & 3000 & 3100 & 3050 & 2920 & 2905 & 3100 & 3200 & 3200 & 3300 \\
\hline 25 & 2500 & 2600 & 2720 & 2800 & 2840 & 2800 & 2600 & 2650 & 2850 & 2980 & 2980 & 3000 \\
\hline 10 & 2293 & 2448 & 2541 & 2551 & 2605 & 2598 & 2320 & 2481 & 2620 & 2700 & 2728 & 2800 \\
\hline $\mathrm{N}$ & 122 & 245 & 499 & 638 & 354 & 157 & 139 & 320 & 808 & 1065 & 606 & 287 \\
\hline
\end{tabular}

Table 4. Percentile distribution of birth length $(\mathrm{cm})$ offirst born and later-born full term infants in the study (sex combined)

Gestational age (weeks)

\begin{tabular}{|c|c|c|c|c|c|c|c|c|c|c|c|c|}
\hline \multirow[t]{2}{*}{ Percentile } & \multicolumn{6}{|c|}{ First born } & \multicolumn{6}{|c|}{ Later born } \\
\hline & 37 & 38 & 39 & 40 & 41 & 42 & 37 & 38 & 39 & 40 & 41 & 42 \\
\hline 90 & 50.5 & 51.0 & 51.0 & 51.0 & 51.5 & 51.5 & 50.9 & 51.0 & 51.0 & 51.5 & 52.0 & 52.1 \\
\hline 75 & 49.0 & 50.0 & 50.0 & 50.0 & 50.2 & 50.2 & 50.0 & 50.0 & 50.2 & 50.6 & 51.0 & 51.0 \\
\hline 50 & 48.0 & 48.5 & 49.0 & 49.3 & 49.5 & 49.5 & 48.6 & 48.6 & 49.2 & 50.0 & 50.0 & 50.0 \\
\hline 25 & 46.5 & 47.2 & 48.0 & 48.2 & 48.1 & 48.2 & 47.0 & 47.0 & 48.0 & 48.5 & 48.2 & 48.5 \\
\hline 10 & 45.5 & 46.0 & 47.0 & 47.1 & 47.0 & 47.0 & 46.0 & 46.0 & 47.0 & 47.0 & 47.0 & 47.5 \\
\hline $\mathrm{N}$ & 122 & 245 & 499 & 638 & 354 & 157 & 139 & 320 & 807 & 1,065 & 606 & 287 \\
\hline
\end{tabular}


to the small number of infants at this gestational period. Another possibility is the effect of placental dysfunction in postmature infants. Here again first-born and later-born full term infants for both sexes were compared (Table 4). For both groups of infants it showed that length was relatively stable after 40 weeks of gestation, however for infants at the 10 percentile, length started to stabilize already at 39 weeks, probably due to early dysfunction of the placenta in borderline small for date infants. It was also evident that parity of mother did not affect the length of the infant.

\section{Head circumference}

The mean head circumference of boys was $3 \mathrm{~mm}$ longer than that of girls (about 1 percent). The growth curve of head circumference flattened after 40 weeks of gestation in both sexes, showing that intrauterine growth in head circumference has reached it maximum at 40 weeks of gestation. The exact figures are seen in subsequent tables and graphs (Annex; Tables IX, X, and XI, and Figures 7,8 , and 9).

There is usually a direct relation between growth in head circumference and crown-heel length during the fetal period, but not in all infants. In perhaps 5 $10 \%$ of infants the head is large or small in proportion to a normal body length or the latter is short or long in proportion to a normal head circumference. ${ }^{5}$ The clinical significance of these disproportions has not been investigated.

Table 5 shows that parity of mother did not consistently affect the infant's head circumference.

\section{Chest circumference}

Compared to other anthropometric measurements, almost no difference between the mean chest cicumference of bab boys and girls was found. Chest circum ference of boys was $0.2 \mathrm{~cm}$ or $0.3 \%$ long er than that of girls. Also here the intra uterine growth curve for chest circumference was relatively stable after 40 weeks of gestation (see Annex; Tables XII, XIII, and XIV, and Figures 10, 11, and 12)

\section{Arm circumference}

The mean arm circumference of boys was $0.1 \mathrm{~cm}$ longer than that of girls, or girls had $2 \%$ shorter arm circumference than that of boys. Arm circumference was relatively constant after 40 weeks of gestation while a difference between boys and girls was found at 36 weeks of gestation (see Annex; Tables XV, XVI, XVII, and Figures 13, 14, and 15).

\section{Relationship of Birthweight to other Anthropometric Measurements}

Some determinations of whether newborn infants are obese, normal, or lean can be made by observation, inspection, and palpation. Determinations of different degrees of obesity and thinness can be made by calculating weight-height ratios or ponderal indices.

\section{The Ponderal Index}

The ponderal index is based on Rohrer's formula as follows:
Birth weight in $g /\left(\right.$ crown-heel length in $\left.\mathrm{cm}^{2}\right) \times 100$

This formula is derived from the observation that the weight of an object of uniform density and dimensions increases as the cube of its length. The advantage of using this formula is that in full term infants of $>38$ weeks or $>48.5$ $\mathrm{cm}$ in body length, the ponderal index apparently is not significantly affected by race, sex, or gestational age. ${ }^{5}$ However care needs to be taken in interpreting ponderal index in infants with disproportional large or small head. The head of an infant is such a large part of the body weight that the ponderal index will be distorted if the head is disproportionately large or small, as it occasionally is in a small percentage of fetuses and newborn infants. The percentile distribution of ponderal indices of the study sample is presented in Annex, boys and girls separated. Interpreting ponderal index is more difficult in premature infants, because of the relatively larger head, the ponderal index may become distorted. According to Miller and Merritt ${ }^{5}$ infants are considered extremely obese who have ponderal indices above 2.93 (95\%) and extremely malnourished if their ponderal indices is below $2.26(5 \%)$.

Comparison of indices of first-born and later-born infants can be seen in the Table 6 , it shows that at the ninetieth percentiles the ponderal indices of later born infants were greater than those of first-born infants, indicating that more infants of multiparae were likely to be obese. The explanation for the increased incidence of obesity among later-born infants may relate to the well recognized weight of multiparous in general and with added years and weight in some multiparous. In our study values for extreme thinness could be found in the 10 percentile of first born infants of less than 40 th weeks of gestation $(10 \%)$ and at 38 th week $(10 \%)$ of later born infants. Extreme obesity was found for later born infants with more than 39th weeks of gestation $(90 \%)$.

\section{Weight to Height Ratios}

For those who prefer weight/height ratios to ponderal indices in the evaluation of infants nutritional status, data on the percentile distribution of birthweights of more than 3539 full term infants are shown in Table 7. Full term infants whose weight-height ratios fall below the 10th percentile for their heights should be considered thin and were probably already malnourished intrauterine.

\section{Relationship between Birthweight and Arm and Chest Circumierences}

In developing countries it is often not possible to weight the baby accurately. This may be due to lack of appropriate and robust weighting scales that can withstand the constant use in the field. Few-authors have addressed this problem; ${ }^{6}$ they are able to identify suitable birth weight nu. - ises. However if use of a surrogate is to be widely recommended, it is necessary that it should be appropriate across national and ethnic boundaries. Before studying the cut-off points, it was necessary to study the relationship between birth weight and arm and chest circumference. 
Table 5. Percentile distribution of head circumference $(\mathrm{cm})$ of first born and later-born full term infants in the study (sex combined)

\begin{tabular}{|c|c|c|c|c|c|c|c|c|c|c|c|c|}
\hline \multicolumn{13}{|c|}{ Gestational age (weeks) } \\
\hline \multirow[t]{2}{*}{ Percentile } & \multicolumn{6}{|c|}{ First born } & \multicolumn{6}{|c|}{ Later born } \\
\hline & 37 & 38 & 39 & 40 & 41 & 42 & 37 & 38 & 39 & 40 & 41 & 42 \\
\hline 90 & 34.5 & 35.0 & 35.0 & 35.0 & 35.6 & 35.5 & 35.0 & 35.0 & 35.3 & 35.6 & 36.0 & 36 \\
\hline 75 & 33.9 & 34.0 & 34.0 & 34.2 & 34.6 & 34.5 & 34.0 & 34.1 & 34.5 & 34.8 & 35.0 & 35.2 \\
\hline 50 & 32.8 & 33.0 & 33.2 & 33.5 & 33.6 & 33.5 & 33.0 & 33.0 & 33.5 & 34.0 & 34.0 & 34.0 \\
\hline 25 & 31.7 & 32.0 & 32.4 & 32.5 & 32.9 & 32.6 & 32.0 & 32.3 & 32.8 & 33.0 & 33.0 & 33.0 \\
\hline 10 & 30.5 & 31.0 & 31.5 & 31.5 & 32.0 & 31.5 & 31.5 & 31.8 & 32.0 & 32.0 & 32.0 & 32.2 \\
\hline $\mathrm{N}$ & 122 & 245 & 499 & 638 & 354 & 157 & 139 & 320 & 807 & 1065 & 606 & 287 \\
\hline
\end{tabular}

Table 6. Percentile distribution of ponderal indices of first born and later-born full term infants in the study (sex combined)

\begin{tabular}{cccccccccccccc}
\hline \multicolumn{10}{c}{ Gestational age-weeks } \\
\hline Percentiles & \multicolumn{10}{c}{ First born } & \multicolumn{1}{c}{ Later born } \\
\hline & 37 & 38 & 39 & 40 & 41 & 42 & 37 & 38 & 39 & 40 & 41 & 42 \\
\hline & 2.78 & 2.81 & 2.83 & 2.84 & 2.91 & 2.79 & 2.91 & 2.95 & 2.94 & 3.00 & 3.02 & 3.01 \\
75 & 2.61 & 2.64 & 2.70 & 2.67 & 2.77 & 2.70 & 2.70 & 2.75 & 2.76 & 2.82 & 2.82 & 2.87 \\
50 & 2.49 & 2.50 & 2.54 & 2.51 & 2.58 & 2.54 & 2.55 & 2.56 & 2.58 & 2.63 & 2.64 & 2.66 \\
25 & 2.31 & 2.33 & 2.39 & 2.36 & 2.41 & 2.41 & 2.38 & 2.38 & 2.44 & 2.46 & 2.49 & 2.49 \\
10 & 2.17 & 2.22 & 2.25 & 2.24 & 2.28 & 2.29 & 2.24 & 2.25 & 2.32 & 2.31 & 2.34 & 2.34 \\
\hline N & 122 & 2.245 & 499 & 638 & 354 & 157 & 139 & 320 & 807 & 1065 & 606 & 287 \\
\hline
\end{tabular}

Table 7. Birthweight $(\mathrm{g})$ to crown-heel length by percentiles (sex combined)

\begin{tabular}{cccccccccccc}
\hline Percentile & \multicolumn{10}{c}{ Crown-heel length $(\mathrm{mm})$} \\
\hline & 47.0 & 47.5 & 48.0 & 48.5 & 49.0 & 49.5 & 50.0 & 50.5 & 51.0 & 51.5 & 52.0 \\
\cline { 2 - 11 } & 3200 & 3201 & 3300 & 3242 & 3405 & 3285 & 3650 & 3514 & 3800 & 3750 & 4000 \\
75 & 3000 & 2973 & 3100 & 3048 & 3250 & 3285 & 3450 & 3400 & 3600 & 3515 & 3800 \\
50 & 2800 & 2800 & 2900 & 2905 & 3035 & 3055 & 3230 & 3200 & 3400 & 3400 & 3567 \\
25 & 2600 & 2590 & 2700 & 2763 & 2880 & 2948 & 3040 & 3000 & 3143 & 3090 & 3350 \\
10 & 2500 & 2500 & 2550 & 2610 & 2700 & 2745 & 2900 & 2837 & 3000 & 2960 & 3200 \\
\hline $\mathrm{N}$ & 345 & 48 & 571 & 84 & 694 & 98 & 928 & 72 & 436 & 54 & 206 \\
\hline
\end{tabular}

Table 8 Correlations between birthweight, arm circumference, and chest circumference for boys

\begin{tabular}{|c|c|c|c|c|c|c|c|c|c|}
\hline & \multirow[t]{2}{*}{ Center University } & \multicolumn{2}{|c|}{ BWIAC } & \multicolumn{2}{|c|}{$\mathrm{BW} / \mathrm{CC}$} & \multicolumn{2}{|c|}{$\mathrm{AC} / \mathrm{CC}$} & \multicolumn{2}{|c|}{ Sample Size } \\
\hline & & Boy & Girl & Boy & Girl & Boy & Girl & Boy & Girl \\
\hline 1 & Unsyah & 49 & 53 & 49 & 44 & 44 & 41 & 382 & 345 \\
\hline 2 & USU & 63 & 69 & 80 & 75 & 58 & 56 & 123 & 123 \\
\hline 3 & Unand & 77 & 64 & 76 & 60 & 65 & 57 & 56 & 40 \\
\hline 4 & Unsri & 25 & 79 & 71 & 79 & 30 & 72 & 279 & 224 \\
\hline 5 & Unsrat & 68 & 69 & 84 & 81 & 67 & 69 & 220 & 182 \\
\hline 6 & Unhas & 74 & 63 & 83 & 77 & 81 & 61 & 197 & 197 \\
\hline 7 & Unair & 86 & 90 & 59 & 91 & 51 & 85 & 146 & 147 \\
\hline 8 & Unibraw & 63 & 66 & 66 & 72 & 61 & 61 & 145 & 135 \\
\hline 9 & UGM & 49 & 44 & 82 & 79 & 40 & 38 & 349 & 313 \\
\hline 10 & Undip & 60 & 37 & 63 & 60 & .. & 28 & 350 & 328 \\
\hline 11 & UNS & 77 & 74 & 85 & 88 & 77 & 77 & 100 & 92 \\
\hline 12 & UI & 70 & 72 & 75 & 67 & 59 & 56 & 213 & 173 \\
\hline 13 & Unpad & 71 & 67 & 68 & 67 & 54 & 53 & 280 & 280 \\
\hline 14 & RSHK & 38 & 77 & 67 & 85 & -24 & 75 & 212 & 213 \\
\hline
\end{tabular}

Note: Decimal points are omitted. 
Table 8 shows the correlations between birthweight and arm and chest circumference. The correlations between birthweight and chest circumference ranging from 0.46-0.82 was higher compared with birthweight and arm circumference (ranging from 0.37-0.75). In 11 out of 14 centers the correlations between birthweight and chest circumference were higher than those with arm circumference, probably due to the fact that chest circumference was more easily and reliably measured that arm circumference. The latter was therefore more subject to measurement error and result in a lower correlation.

Table 9 shows the regression of birth weight on arm and chest circumference for all data combined. A better relationship between birth weight and chest circumference than between birth weight and arm circumference was observed.

\section{Birth Weight Surrogates}

In developing countries suitable surrogates for birthweight is important because the difficulty to weight the infant accurately. This is particularly important to identify low birth weight babies using a simple measuring instrument. It must be consistenly accurate over the first few days of life as in rural areas a baby may not be seen by a health worker until it is a few days old. ${ }^{6}$

\section{The Prediction of Low Birth Weight}

The prediction of low birth weight using arm and chest circumference requires the choice of cut-off and end points. The end was chosen at $<2500$ grams for all
Table 9. Regression of birth-weight on arm and chest circumference for all data combined

\begin{tabular}{lrrr}
\hline & Coefficient & $\begin{array}{c}\text { Standard } \\
\text { Error }\end{array}$ & $\mathrm{R}^{2}$ \\
\hline Constant & $1,078,032$ & 43.41 & \\
AC & 182,150 & 3.96 & 0.27 \\
Sex & 54.16 & 9.94 & \\
Constant & $-1,530,964$ & 66,235 & \\
CC & 141,129 & 2,032 & 0.46 \\
Sex & 51.84 & 8.59 & \\
Constant & $-1,721,279$ & 63,289 & \\
AC & 95,081 & 3,628 & 0.51 \\
Chest & 116,046 & 2,157 & \\
\hline
\end{tabular}

centers according to the definition of the World Health Organization. $^{6}$

Some centers had small numbers (less than 5 infants). The result shows that at arm circumference of $<9.0$ and $<9.5$ centimeters and chest circumference of $<28$ $\mathrm{cm}$ and $<29 \mathrm{~cm}$ both the sensitivity and positive predictive values were relatively high. It also shows that a chest circumference of $<29 \mathrm{~cm}$ was a better predictor for birth weight and tended to be higher than for arm circumference of $<9 \mathrm{~cm}$.

As recommended by $\mathrm{WHO}^{6}$ to identify the optimum cut-off point for each center it is necessary to estimate the probability of a LBW infant for a range of specific points and choose the best for the particular center using a logistic regression model as seen on Tables 15 and 16. 
Table 10. Regression of birth weight on arm circumference $(\mathrm{cm})$

\begin{tabular}{|c|c|c|c|c|c|c|c|}
\hline & \multirow[t]{2}{*}{ University } & \multirow[t]{2}{*}{$n$} & Constant & Sex & Arm. Circ. & Arm Sex & \multirow[t]{2}{*}{$\mathrm{R}^{2}$} \\
\hline & & & (SE) & (SE) & (SE) & (SE) & \\
\hline \multirow[t]{2}{*}{1} & Unsyiah & 727 & $-24,797$ & 253441 & 281621 & -19851 & 0.263 \\
\hline & & & 285,339 & 392,807 & $24,693$. & 33,924 & \\
\hline \multirow[t]{2}{*}{2} & USU & 246 & $-630,560$ & 763,082 & 355,109 & $-66,942$ & 0.437 \\
\hline & & & 382,963 & 517,881 & 34,631 & 46,926 & \\
\hline \multirow[t]{2}{*}{3} & Unand & 96 & 95,301 & $-327,451$ & 260,777 & 44,337 & 0.541 \\
\hline & & & 499,637 & 645,667 & 45,703 & 58,819 & \\
\hline \multirow[t]{2}{*}{4} & Unsri & 503 & $-772,800$ & $3,179,968$ & 365,922 & $-306,461$ & 0.289 \\
\hline & & & 284,493 & 310,668 & 27,588 & 29,970 & \\
\hline \multirow[t]{2}{*}{5} & Unsrat & 402 & $-1,492,956$ & $-189,024$ & 391,427 & 25,006 & 0.467 \\
\hline & & & 383,034 & 503,461 & 33,408 & 44,082 & \\
\hline \multirow[t]{2}{*}{6} & Unhas & 394 & 621,357 & $-1,379,623$ & 236,124 & 142,362 & 0.480 \\
\hline & & & 206,166 & 329,129 & 20,396 & 32,453 & \\
\hline \multirow[t]{2}{*}{7} & Unair & 293 & $-1,620,165$ & 441,362 & 451,806 & $-34,173$ & 0.783 \\
\hline & & & 190,076 & 271,308 & 18,904 & 27,094 & \\
\hline \multirow[t]{2}{*}{8} & Unibraw & 280 & $-370,399$ & 154,262 & 304,315 & $-6,416$ & 0.420 \\
\hline & & & 345,422 & 481,813 & 30,670 & 42,926 & \\
\hline \multirow[t]{2}{*}{9} & UGM & 662 & $1,698,842$ & $-202,009$ & 116,536 & $26,48^{\prime} 8$ & 0.223 \\
\hline & & & 150,872 & 211,074 & 13,855 & 19,405 & \\
\hline \multirow[t]{2}{*}{10} & Undip & 678 & $1,902,773$ & $-1,749,902$ & 103,987 & 166,987 & 0.265 \\
\hline & & & 145,640 & 282,611 & 13,192 & 25,349 & \\
\hline \multirow[t]{2}{*}{11} & UNS & 192 & $-238,973$ & $-564,687$ & 295,115 & 55,483 & 0.578 \\
\hline & & & 315,097 & 440,116 & 29,282 & 40,696 & \\
\hline \multirow[t]{2}{*}{12} & UI & 386 & $-40,964$ & $-72,353$ & 308,508 & 8,637 & 0.501 \\
\hline & & & 236,789 & 330,747 & 23,237 & 32,225 & \\
\hline \multirow[t]{2}{*}{13} & Unpad & 560 & $-237,920$ & $-221,653$ & 286,992 & 23,258 & 0.484 \\
\hline & & & 210,264 & 304,861 & 18,382 & 26,472 & \\
\hline \multirow[t]{2}{*}{14} & RSHK & 425 & $-617,255$ & $2,750,175$ & 360,844 & $-262,983$ & 0.36 \\
\hline & & & 280,449 & 317,089 & 26,849 & 30,207 & \\
\hline
\end{tabular}


Table 11. Regression of birth weight on chest circumference $(\mathrm{cm})$

\begin{tabular}{|c|c|c|c|c|c|c|c|}
\hline \multirow{2}{*}{\multicolumn{2}{|c|}{$\begin{array}{c}\text { Center } \\
\text { University }\end{array}$}} & \multirow[t]{2}{*}{$n$} & Constant & Sex & Chest circ. & $\begin{array}{l}\text { Chest/ } \\
\text { Sex }\end{array}$ & \multirow[t]{2}{*}{$R^{2}$} \\
\hline & & & (SE) & (SE) & (SE) & (SE) & \\
\hline \multirow{2}{*}{\multicolumn{2}{|c|}{1 Unsyah }} & 727 & -949340 & -218450 & 68,584 & 7,805 & 0.220 \\
\hline & & & 250,347 & 342,526 & 7,531 & 10,308 & \\
\hline \multirow{2}{*}{\multicolumn{2}{|c|}{2 USU }} & 246 & $-2,485,307$ & $-291,876$ & 174,302 & 9,514 & 0.594 \\
\hline & & & 444,067 & 630,121 & 13,392 & 19,025 & \\
\hline \multirow{2}{*}{\multicolumn{2}{|c|}{3 Unand }} & 96 & $-3,252,586$ & $-548,821$ & 194,384 & 18,266 & 0.507 \\
\hline & & & $1,211,152$ & $1,501,001$ & 38,035 & 46,765 & \\
\hline \multirow{2}{*}{\multicolumn{2}{|c|}{4 Unsri }} & 503 & $-2,820,549$ & 455,651 & 181,652 & $-12,430$ & $0: 551$ \\
\hline & & & 346,598 & 457,080 & 10,826 & 14,291 & \\
\hline \multirow{2}{*}{\multicolumn{2}{|c|}{5 Unsrat }} & 402 & $-3,246,898$ & $-547,760$ & 191,221 & 18,381 & 0.680 \\
\hline & & & 349,683 & 458,155 & 10,713 & 14,034 & \\
\hline \multirow{2}{*}{\multicolumn{2}{|c|}{6 Unhas }} & 394 & $-3,620,503$ & 29,199 & 207,757 & 0.441 & 0.650 \\
\hline & & & 384,661 & 503,675 & 12,071 & 15,766 & \\
\hline \multirow{2}{*}{\multicolumn{2}{|c|}{7 Unair }} & 293 & $-3,777,096$ & $4,236,807$ & 213,629 & $-133,836$ & 0.610 \\
\hline & & & 372,805 & 438,231 & 11,897 & 13,949 & \\
\hline \multirow{2}{*}{\multicolumn{2}{|c|}{8 Unibraw }} & 280 & $-2,624,566$ & 100,138 & 173,485 & $-2,371$ & 0.489 \\
\hline & & & 491,323 & 709,386 & 15,008 & 21,597 & \\
\hline \multirow{2}{*}{\multicolumn{2}{|c|}{9 UGM }} & 662 & $-2,322,846$ & $-420,089$ & 163,242 & 15,913 & 0.649 \\
\hline & & & 234,486 & 321,227 & 7,239 & 9,927 & \\
\hline \multirow{2}{*}{\multicolumn{2}{|c|}{10 Undip }} & 678 & $-2,140,866$ & 137,336 & 158,349 & $-2,380$ & 0.392 \\
\hline & & & 369,421 & 515,926 & 11,277 & 15,638 & \\
\hline \multirow{2}{*}{\multicolumn{2}{|c|}{11 UNS }} & 132 & $-2,543,595$ & $-434,402$ & 169,799 & 14,157 & 0.744 \\
\hline & & & 358,277 & 494,796 & 11,106 & 15,280 & \\
\hline \multirow{2}{*}{\multicolumn{2}{|c|}{12 UI }} & 386 & $-1,602,779$ & $-1,408,064$ & 144,396 & 43,921 & 0.513 \\
\hline & & & 375,670 & 547,366 & 11,540 & 16,752 & \\
\hline \multirow{2}{*}{\multicolumn{2}{|c|}{13 Unpad }} & 560 & $-2,299,617$ & 298,853 & 162,167 & $-7,347$ & 0.462 \\
\hline & & & 352,026 & 485,774 & 10,691 & 14,705 & \\
\hline \multirow{2}{*}{\multicolumn{2}{|c|}{14 RSHK }} & 425 & $-3,688,869$ & $2,831,345$ & 212,534 & $-86,821$ & 0.573 \\
\hline & & & 375,253 & 458,991 & 11,667 & 14,282 & \\
\hline
\end{tabular}

Table 12. Percentage of infants weighing less than 2500 gram by center

\begin{tabular}{|c|c|c|c|c|}
\hline & \multirow[t]{2}{*}{ Center } & \multirow{2}{*}{$\begin{array}{l}\text { Total no. } \\
\text { of infants }\end{array}$} & \multicolumn{2}{|c|}{$<2500 \mathrm{~g}$} \\
\hline & & & $\mathrm{n}$ & $\%$ \\
\hline & Unsyiah & 727 & 17 & 2.3 \\
\hline & USU & 246 & 1 & 0.4 \\
\hline & Unand & 96 & 13 & 13.5 \\
\hline & Unsri & 503 & 42 & 10.5 \\
\hline & Unsrat & 402 & 42 & 10.4 \\
\hline & Unhas & 394 & 40 & 10.2 \\
\hline & Unair & 293 & 38 & 13.0 \\
\hline & Unibraw & 280 & 1 & 0.4 \\
\hline & UGM & 662 & 58 & 8.8 \\
\hline & Undip & 678 & 38 & 5.6 \\
\hline & UNS & 192 & 17 & 8.9 \\
\hline 12 & UI & 386 & 9 & 2.3 \\
\hline 13 & Unpad & 560 & 22 & 3.9 \\
\hline 14 & RSHK & 425 & 20 & 4.7 \\
\hline & Total & 5,844 & 369 & 6.3 \\
\hline
\end{tabular}

The estimated probabilities for low birth infants using different cut-off points can be seen in Table 17. As can be seen from this table, the probability for low birth weight became smaller as the measurements higher. A cut off point of $<9 \mathrm{~cm}$ for arm circumference was probably appropriate for all centers as well as a cut-off point of $<29 \mathrm{~cm}$ for chest circumference, for indicating low birth weight.

\section{Discussion}

The major objective of this study is the need for a reference intrauterine curve based on measurements of newborn infants who have been unencumbered by known growth retarding influences in uteri, so far as could be determined from review of their mothers medical and obstetric histories and from examination of the infants. By excluding all infants with known growth retarding conditions from the sample size a better opportunity is afforded in diagnosing excessive fetal undergrowth and overgrowth and in elucidating their causes in future studies.

Indonesian pediatricians have almost always been using the Denver Intrauterine growth which is in fact different to our result. The Denver data conducted in 1948-1961 shows a mean birth weight of $35 \mathrm{~g}$ higher compared to the Indonesia data. While the data from Gruenwald ${ }^{10}$ in Baltimore and McKeon in Birmingham ${ }^{11}$ have higher mean birth weights. The main reason of using the intrauterine growth curve from Denver was that a comprehensive survey to study birth weight in Indonesia is difficult because more than $80 \%$ of babies are born outside the hospital.

This lead to the question whether infants born in the hospital as conducted in this survey, is a representative sample for the population. However, at this moment this may be the only way to collect anthropometric data of newborns using a very tight inclusion criteria.

Previous investigators had not excluded all infants associated with any intrauterine growth-retarding factors from their published data which probably may 
Table 13. Test sensitivities and positive predictive values using different cut-off values for a birth weight below 2500 grams by chest circumference

\begin{tabular}{|c|c|c|c|c|c|c|c|c|c|}
\hline \multirow[t]{2}{*}{ Center } & \multicolumn{2}{|c|}{ Chest $<28 \mathrm{~cm}$} & \multirow{2}{*}{$n$} & \multicolumn{2}{|c|}{ Chest $<29 \mathrm{~cm}$} & \multirow{2}{*}{$\mathrm{n}$} & \multicolumn{2}{|c|}{ Chest $<30 \mathrm{~cm}$} & \multirow{2}{*}{$n$} \\
\hline & Sens. \% & PPV \% & & Sens. \% & PPV \% & & Sens. \% & PPV \% & \\
\hline Unsyah & 17.6 & 7.1 & 3 & 17.6 & 6.7 & 3 & 23.5 & 6.7 & 4 \\
\hline USU & - & - & - & - & - & - & 100.0 & 50.0 & 1 \\
\hline Unand & - & - & - & 7.7 & 100.0 & 1 & 23.1 & 100.0 & 3 \\
\hline Unsri & 20.8 & 78.6 & 11 & 52.8 & 77.8 & 28 & 69.8 & 62.7 & 37 \\
\hline Unsrat & 16.7 & 100 & 7 & 26.2 & 100.0 & 11 & 54.8 & 95.8 & 23 \\
\hline Unhas & 32.5 & 92.9 & 13 & 50.0 & 90.9 & 20 & 65.0 & 68.4 & 26 \\
\hline Unair & 31.6 & 85.7 & 12 & 57.9 & 91.7 & 22 & 84.2 & 64.0 & 32 \\
\hline Unibraw & $\cdot$ & - & - & - & $\cdot$ & - & - & - & - \\
\hline UGM & 29.3 & 100.0 & 17 & 48.3 & 100.0 & 28 & 69.0 & 74.1 & 40 \\
\hline Undip & 5.3 & 66.7 & 2 & 7.9 & 75 & 3 & 28.9 & - 78.6 & 11 \\
\hline UNS & 35.3 & 100 & 6 & 76.5 & 100 & 13 & 88.2 & 78.9 & 15 \\
\hline UI & $\cdot$ & - & - & 33.3 & 42.9 & 3 & 55.6 & 29.4 & 5 \\
\hline Unpad & 4.5 & 100.0 & 1 & 22.7 & 83.3 & 5 & 27.3 & 46.2 & 6 \\
\hline RSHK & 30 & 85.7 & 6 & 60 & 92.3 & 12 & 80.0 & 47.1 & 16 \\
\hline Total & 21.1 & 61.4 & 78 & 40.4 & 71.0 & 149 & 59.3 & 56.3 & 219 \\
\hline
\end{tabular}

Sens. = sensitivity

PPV = positive predictive value

$n=$ number of infants
Table 14. Test sensitivities and positive predictive values using different cut-off values for a birth weight below 500 grams by arm circumference

\begin{tabular}{|c|c|c|c|c|c|c|c|c|c|}
\hline \multirow[t]{2}{*}{ Center } & \multicolumn{3}{|c|}{ Arm $<9 \mathrm{~cm}$} & \multicolumn{3}{|c|}{ Arm $<9.5 \mathrm{~cm}$} & \multicolumn{3}{|c|}{ Arm $<10 \mathrm{~cm}$} \\
\hline & Sens (\%) & PPV (\%) & $n$ & Sens (\%) & $\operatorname{PPV}(\%)$ & $n$ & Sens (\%) & PPV (\%) & $\mathrm{n}$ \\
\hline Unsyah & 5.9 & 100 & 1 & 17.6 & 100.0 & 3 & 17.6 & 100.0 & 3 \\
\hline USU & - & - & - & $\cdot$ & $\cdot$ & - & 100.0 & 6.7 & 1 \\
\hline Unand & 15.4 & 100.0 & 2 & 30.8 & 50 & 4 & 38.5 & 50.0 & 5 \\
\hline Unsri & 54.7 & 725 & 29 & 77.4 & 46.1 & 41 & 84.9 & 32.6 & 45 \\
\hline Unsrat & 2.4 & 100.0 & 1 & 11.9 & 83.3 & 5 & 26.2 & 84.6 & 11 \\
\hline Unhas & 60.0 & 60.0 & 24 & 82.5 & 37.1 & 33 & 92.5 & 21.4 & 37 \\
\hline Unair & 65.8 & 83.3 & 25 & 86.8 & 45.2 & 33 & 100.0 & 26.2 & 38 \\
\hline Unibraw & $\cdot$ & - & - & - & - & - & - & $\cdot$ & - \\
\hline UGM & 27.6 & 80.0 & 16 & 63.8 & 62.7 & 37 & 72.4 & 44.7 & 42 \\
\hline Undip & 10.5 & 100.0 & 4 & 21.1 & 42.1 & 8 & 50.0 & 38.0 & 19 \\
\hline UNS & 47.1 & 88.9 & 8 & 70.6 & 85.7 & 12 & 100 & 68 & 17 \\
\hline UI & 66.7 & 26.1 & 6 & 66.7 & 8.0 & 6 & 88.9 & 5.4 & 8 \\
\hline Unpad & 22.7 & 71.4 & 5 & 31.8 & 77.8 & 7 & 40.9 & 36.0 & 9 \\
\hline RSHK & 30.0 & 85.7 & 6 & 75.0 & 28.8 & 15 & 85.0 & 25.0 & 17 \\
\hline Total & 34.4 & 69.0 & 127 & 55.3 & 40.9 & 204 & 68.3 & 27.6 & 252 \\
\hline
\end{tabular}


Table 15. Logistic regression of birth weight on chest circumference

\begin{tabular}{|c|c|c|c|c|c|}
\hline Center & Constant & Coefficient & S.E. (coeff) & OR & Signif. \\
\hline Unsyiah & -3.2578 & 0.2197 & 0.5500 & 1.1161 & $\cdots$ \\
\hline USU & -70.9760 & 2.4631 & 1.4491 & 3.4265 & NS \\
\hline Unand & -76.7579 & 2.5373 & 0.7135 & 3.5564 & $\cdots$ \\
\hline Unsri & -33.9568 & 1.1749 & 0.1393 & 1.7993 & $\cdots$ \\
\hline Unsrat & -59.4266 & 1.9773 & 0.2865 & 2.6972 & *.. \\
\hline Unhas & -40.3657 & 1.3797 & 0.1923 & 1.9934 & $* *$ \\
\hline Unair & -32.4295 & 1.1288 & 0.1740 & 1.7584 & $\cdots$ \\
\hline Unibraw & 32.0790 & -0.0724 & 0.5444 & 0.6762 & NS \\
\hline UGM & -47.6385 & 1.6226 & 0.1911 & 2.2508 & $\ldots$ \\
\hline Undip & -30.7293 & 1.0509 & 0.1424 & 1.6912 & **** \\
\hline UNS & 76.5377 & 2.6179 & 0.7233 & 3.7025 & $* *$ \\
\hline UI & -14.8198 & 0.5836 & 0.1795 & 1.3388 & $\ldots$ \\
\hline Unpad & -30.2579 & 1.0536 & 0.1693 & 1.6935 & $\cdots$ \\
\hline RSHK & -23.3016 & 0.8515 & 0.1524 & 1.5307 & $\cdots$ \\
\hline $\begin{array}{l}\text { OR } \\
: \\
\cdots \\
\text { NS }\end{array}$ & \multicolumn{5}{|c|}{$\begin{array}{l}=\text { Odds ratio }=e \text { (coeff. } 20.5 \text { ) } \\
=\text { significant at } 0.05 \\
=\text { significant at } 0.01 \\
=\text { significant at } 0.000 \\
=\text { not significant }\end{array}$} \\
\hline
\end{tabular}

Table 16. Logistic regression of birth weight on arm circumference

\begin{tabular}{lccccc}
\hline Center & Constant & Coefficient & SE (coeff) & OR & Signif. \\
\hline Unsyiah & -18.6963 & 2.0352 & 0.4071 & 2.7667 & $\ldots$ \\
USU & -20.6135 & 2.5175 & 1.6393 & 3.5219 & NS \\
Unand & -17.0371 & 1.83 & 0.4898 & 1.4865 & $\ldots$ \\
Unsri & -5.8064 & 0.7927 & 0.1504 & 1.4865 & $\ldots$ \\
Unsrat & -23.5288 & 2.3740 & 0.3107 & 3.2333 & $\ldots$ \\
Unhas & -22.7480 & 2.6386 & 0.3727 & 3.7408 & $\ldots$ \\
Unair & -34.1172 & 3.8295 & 0.6135 & 6.7852 & $\ldots$ \\
Unibraw & 19.6625 & -1.2114 & 1.1680 & 0.5662 & NS \\
UGM & -23.0845 & 2.5431 & 0.2871 & 3.5662 & $\ldots$ \\
Undip & -16.9798 & 1.8951 & 0.2650 & 2.5794 & $\ldots$ \\
UNS & -41.2537 & 4.4507 & 1.0970 & 9.2581 & $\ldots$ \\
UI & -20.2046 & 2.5116 & 0.6164 & 3.5106 & $\ldots$ \\
UnsH & -14.4031 & 1.6298 & 0.2570 & 2.2589 & $\ldots$ \\
\hline & -22.1513 & 2.5591 & 0.4606 & 3.6658 & $\ldots$ \\
\hline
\end{tabular}


Table 17. Estimated probabilities of BW below 2500 gram for a range of arm and chest circumferences

\begin{tabular}{|c|c|c|c|c|}
\hline University & $A C$ & Prob. LBW & CC & Prob LaW \\
\hline \multirow[t]{6}{*}{ Unsyah } & 8.0 & 0.92 & 28 & 0.05 \\
\hline & 8.5 & 0.80 & $29^{\circ}$ & 0.04 \\
\hline & 9.0 & 0.59 & 30 & 0.03 \\
\hline & 9.5 & 0.35 & 31 & 0.03 \\
\hline & 10.0 & 0.16 & 32 & 0.02 \\
\hline & 10.5 & 0.06 & 33 & 0.02 \\
\hline \multirow[t]{6}{*}{ usu } & 8.0 & 0.62 & 28 & 0.88 \\
\hline & 85 & 0.31 & 29 & 0.39 \\
\hline & 9.0 & 0.11 & 30 & 0.05 \\
\hline & 9.5 & 0.04 & 31 & 0.00 \\
\hline & 10.0 & 0.01 & 32 & 0.00 \\
\hline & 105 & 0.00 & 33 & 0.00 \\
\hline \multirow[t]{6}{*}{ Unand } & 80 & 0.92 & 28 & 1.00 \\
\hline & 8.5 & 0.81 & 29 & 0.96 \\
\hline & 90 & 0.63 & 30 & 0.65 \\
\hline & 9.5 & 0.41 & 31 & 0.13 \\
\hline & 100 & 0.22 & 32 & 0.01 \\
\hline & 10.5 & 0.10 & 33 & 0.00 \\
\hline \multirow[t]{6}{*}{ Unsti } & 8.0 & 0.37 & 28 & 0.74 \\
\hline & 85 & 0.28 & 29 & 0.47 \\
\hline & 90 & 0.21 & 30 & 022 \\
\hline & 9.5 & 0.15 & 31 & 0.08 \\
\hline & 10.0 & 0.11 & 32 & 0.03 \\
\hline & 10.5 & 0.07 & 33 & 0.01 \\
\hline \multirow[t]{6}{*}{ Unsrat } & 80 & 0.99 & 28 & 0.98 \\
\hline & 8.5 & 0.97 & 29 & 0.89 \\
\hline & 90 & 0.90 & 30 & 0.53 \\
\hline & 95 & 0.73 & 31 & 0.13 \\
\hline & 100 & 0.45 & 32 & 0.02 \\
\hline & 10.5 & 0.20 & 33 & 0.00 \\
\hline \multirow[t]{6}{*}{ Unhas } & 80 & 0.84 & 28 & 0.85 \\
\hline & 8.5 & 0.58 & 29 & 0.59 \\
\hline & 90 & 0.27 & 30 & 0.26 \\
\hline & 9.5 & 0.09 & 31 & 0.08 \\
\hline & 10.0 & 0.03 & 32 & 0.02 \\
\hline & 10.5 & 0.01 & 33 & 0.01 \\
\hline \multirow[t]{3}{*}{ Unair } & 80 & 0.97 & 28 & 0.69 \\
\hline & 85 & 0.83 & 29 & 0.42 \\
\hline & 90 & 0.41 & 30 & 019 \\
\hline
\end{tabular}

Table 17 (continued)

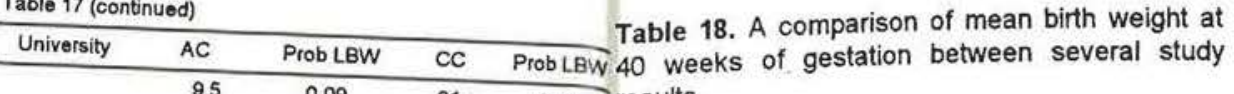
$\begin{array}{lllll}9.5 & 0.09 & 31 & 0.07 & \text { results }\end{array}$

$\begin{array}{llll}0.0 & 02 & 32 & 0.02\end{array}$

$0.5 \quad 0.00$

$10.5 \quad 0.20$

UGM $8.0 \quad 0.94$ $8.5 \quad 0.81$ $9.0 \quad 0.55$ 9.5 0.25 10.0

\begin{tabular}{|c|c|c|c|}
\hline Country & $\begin{array}{c}\text { Year \& } \\
\text { Place of } \\
\text { study }\end{array}$ & Author & $\begin{array}{c}\text { Mean } \\
\text { BW } \\
\text { (gram) }\end{array}$ \\
\hline $\begin{array}{l}\text { Denver } \\
\text { (USA) }\end{array}$ & $\begin{array}{c}\text { 1948-1961, } \\
\text { Hospital }\end{array}$ & Lubchenco & 3220 \\
\hline Baltimore & & Gruenwald & 3318 \\
\hline Birmingham & & Mckeown & 3434 \\
\hline Indonesia & $\begin{array}{l}\text { 1990-1991, } \\
14 \text { Hospitals }\end{array}$ & Alisyahbana & 3085 \\
\hline
\end{tabular}

reflect the investigators desires to present data representative of a given population rather than statistics on normally growth fetuses. ${ }^{5}$ The exclusion of all infants with unknown gestational age and with any fetal or maternal growth retarding factors result in the large number of infants who were excluded from the survey. This is expected in teaching hospitals and a tertiary medical center. The other consequence is that the result of the study represent women from better socioeconomic and educational levels than the total population. It probably will also give a picture of infants born from better nutrional status as women tend to come from better conditions. Considering the limitation of the study the research team have analyzed the data for inter-center as well as international com- parison. The present material of 5844 newborn infants were selected to contain a low proportion of preterm and high proportion of term infants. The summary statistics for birth weight, upper arm circumference and chest circumference can be seen in Table 19. It shows that the Indonesian data differed not very much to other countries in Asia, racial and nutritional factors may be the some of the reasons for lack of difference.

While Indonesian Pediatrician have always use the Denver intrauterine growth curve it is important to analyze whether the Denver Curve is really appropriate for the Indonesian tables. To provide the answer to this question the mean birth weight and standard deviation of both studies were compared showing the following result.

The number of infants included fo comparison were from gestational age 34 weeks until 42 weeks. The reason is that for infants less than 34 weeks the number of Indonesian infants were too small and over 42 weeks there were no information from the Denver study. It is interesting to find babies with higher birth weights in the Indonesian sample compared to the Denver babies. After 40 weeks birth weight for Denver babies were higher while Indonesian babies were showing a slower increase. The mean birth weight for each group was compared (3081.5 gram, SD 248.96 of Denver study versus 3073.3 gram, SD 132.75 for the Indonesian infants) a significant difference was found (student $T$ test, $p<0.035$ ). Based on this finding, the Denver intrauterine growth curve can not be used as reference for Indonesian babies. We also have to consider that 
Table 19. A comparison between mean birth weight, upper arm circumference, and chest circumference and the tenth percentile at each country

\begin{tabular}{|c|c|c|c|c|c|c|c|c|c|c|}
\hline \multirow[t]{2}{*}{ Country } & \multirow{2}{*}{$\begin{array}{c}\mathrm{n} \\
\text { Infants }\end{array}$} & \multicolumn{3}{|c|}{ Birth weight } & \multicolumn{3}{|c|}{ Upper arm circumference } & \multicolumn{3}{|c|}{ Chest circumference } \\
\hline & & $\mathrm{x}$ & SD & $10 \mathrm{pct}$ & $\mathrm{x}$ & SD & $10 \mathrm{pct}$ & $x$ & SD & $10 \mathrm{pct}$ \\
\hline Yerevan & 400 & 3295 & 503.9 & 2700 & 11.5 & 1.2 & 10.0 & 33.8 & 2.4 & 30.0 \\
\hline Beijing & 400 & 3175 & 543.1 & 2400 & 10.4 & 1.0 & 9.0 & 33.8 & 2.4 & 30.0 \\
\hline Salvador & 100 & 3394 & 453.6 & 2710 & 11.0 & 0.9 & 10.0 & 33.3 & 1.9 & 30.5 \\
\hline Santiago & 317 & 3224 & 510.2 & 2596 & 10.8 & 1.0 & 9.6 & 32.9 & 2.1 & 30.0 \\
\hline Havana & 442 & 3253 & 528.6 & 2633 & 11.3 & 1.1 & 10.0 & 33.1 & 1.8 & 31.0 \\
\hline Addis Ababa & 430 & 2901 & 598.8 & 2160 & 11.0 & 1.3 & 9.4 & 32.3 & 2.8 & 28.9 \\
\hline Gaza & 529 & 3285 & 533.6 & 2590 & 10.4 & 1.0 & 9.2 & 32.3 & 2.1 & 29.9 \\
\hline Szeged & 1000 & 3279 & 461.4 & 2689 & 10.5 & 0.9 & 9.5 & 31.8 & 2.0 & 29.0 \\
\hline New Delhi (A) & 334 & 2798 & 540.7 & 2065 & 9.2 & 1.0 & 8.0 & 30.0 & 2.4 & 27.0 \\
\hline Chandigarh & 400 & 2850 & 530.6 & 2102 & 9.9 & 1.0 & 8.9 & 31.1 & 1.9 & 28.8 \\
\hline New Delhi (B) & 260 & 2634 & 478.6 & 2040 & 9.0 & 0.9 & 8.0 & 29.6 & 2.5 & 35.1 \\
\hline Seoul & 187 & 3187 & 402.8 & 2648 & 10.3 & 0.8 & 9.2 & 32.4 & 1.7 & 30.2 \\
\hline Nairobi & 400 & 2957 & 600.5 & 2355 & 10.4 & 1.2 & 9.0 & 30.8 & 2.5 & 28.0 \\
\hline Islamabad & 103 & 3209 & 437.4 & 2722 & 10.8 & 0.8 & 10.0 & 32.9 & 2.1 & 30.0 \\
\hline Riyadh & 400 & 3199 & 421.4 & 2655 & 10.8 & 0.8 & 10.3 & 33.2 & 1.8 & 31.0 \\
\hline Dakar & 140 & 2964 & 629.1 & 1950 & 9.7 & 1.4 & 7.8 & 30.0 & 3.1 & 29.3 \\
\hline Shanghai & 400 & 3244 & 422.8 & 2755 & 10.8 & 0.9 & 9.8 & 32.9 & 1.8 & 30.7 \\
\hline Singapore & 404 & 3163 & 448.9 & 2615 & 10.1 & 0.8 & 9.1 & 32.0 & 1.9 & 29.8 \\
\hline Bangkok & 430 & 2986 & 415.9 & 2411 & 10.5 & 0.9 & 10.5 & 31.9 & 1.9 & 29.5 \\
\hline Istambul & 290 & 3205 & 597.6 & 2491 & 10.5 & 1.1 & 9.2 & 33.3 & 2.7 & 32.0 \\
\hline Leningrad & 401 & 3436 & 430.3 & 2900 & 11.3 & 0.9 & 10.0 & 34.0 & 1.7 & 32.0 \\
\hline Hanoi & 427 & 2866 & 524.0 & 1999 & 9.8 & 1.1 & 8.3 & 30.4 & 2.7 & 26.6 \\
\hline Indonesia & 5844 & 3085 & 444.0 & 2429 & 10.9 & 1.7 & 9.3 & 32.5 & 2.1 & 31.4 \\
\hline
\end{tabular}

• Source WHO "Birth weight surrogates" MCH/87.8 
Table 20. Birth weight (gram) of the Denver study and the indonesian study (singleton, male and female)

\begin{tabular}{crrrr}
\hline & \multicolumn{2}{c}{ Denver Study } & \multicolumn{2}{c}{ Indonesian Study } \\
\cline { 2 - 5 } $\begin{array}{c}\text { GA } \\
\text { (weeks) }\end{array}$ & $\begin{array}{r}\text { Nof of } \\
\text { Infants }\end{array}$ & $\begin{array}{c}\text { Mean } \\
\text { BW }\end{array}$ & $\begin{array}{c}\text { No of } \\
\text { infants }\end{array}$ & $\begin{array}{c}\text { Mean } \\
\text { BW }\end{array}$ \\
\hline 34 & 145 & 2278 & 43 & 2553 \\
35 & 188 & 2483 & 70 & 2704 \\
36 & 202 & 2753 & 136 & 2849 \\
37 & 372 & 2800 & 262 & 2819 \\
38 & 636 & 3025 & 565 & 2903 \\
39 & 1010 & 3130 & 1309 & 3066 \\
40 & 1164 & 3226 & 1710 & 3146 \\
41 & 632 & 3307 & 962 & 3205 \\
42 & 336 & 3308 & 446 & 3228 \\
\hline
\end{tabular}

the Denver study was conducted on an altitude of 10.000 feet while most of city of pariticaping universities were between $300-1800$ feet high. ${ }^{1,15}$

To correlate the five anthropometric parameters to gestational age at birth (linear regression analysis) it was found that crown-heel length did not correlate any better than birth weight to gestational age. Whereas chest circumference and arm circumference had a higher degree of correlation to birth weight. This result is important because chest circumference and upper arm circumference is a simple anthropometric measurements: there are few standard curves relating to gestational age. The high correlation efficient of chest circumference and arm circumference as compared to other parameters was evident for boys and girls separately as well as a group. This result was almost the same for Scandinavian infants. ${ }^{4}$ When the Indonesian data is compared to other countries, there are clear differences between the countries in the arithmetical means and percentiles of bothbirth weight and surrogates. The centers in South East Asia have on average the lowest values whereas those in Europe have among the highest. Indonesia values are higher compared to Bangkok but lower than Singapore. (Table19).

The fact that a nearly constant mean weight after 40 completed weeks seems to be a reality found not only in this study. Rooth et $\mathrm{al}^{7}$ reported a similar findings; however they found a constant mean weight after 41 weeks. The explanation is probably the supply of nutrients to the fetus.

According to Root, if the results are confirmed -which requires longitudinal measurements before and after birth- for instance by ultrasound technic, they would reinforce the notion that after 41 completed weeks, pregnancies should be watched carefully as growth retardation may be the first step to fetal morbidity, in the Indonesian study it probably started at 40 weeks. Dunn ${ }^{13}$ reported the same findings in his study.

Recent evidence suggest that during intra uterine life the fetus is not completely protected form harmful environmental influences. This further support the use of birth weight as an important health and development indicator. Birth weight is a measure of a period of rapid growth which is well defined and can be 
considered a more sensitive indicator than later stages of development. ${ }^{8}$

Much have been written about low birth weight (LBW) infants (< 2500 gm) They constitute a heterogeneous group, including premature infants $(<37 \mathrm{com}$ pleted weeks of gestation) and at least the two main types of fetal growth re tardation (FGR) seen in infants of 37 weeks or more. Their importance as a group depends on two factors. They are easily diagnosed by the simple process of weighing them and they provide as a group, a good indication of the degree of prenatal care of mothers and their fetuses. It is generally recognized that any substantial reduction in their number will lower infant mortality and dimished long-term morbidity caused by premature birth and severe fetal growth retardation.'

Low birth weight is not specially studied because it was not the purpose of this survey, however in this sample size low birth weight infants constitutes only for $6.3 \%$ which is much lower than the prevalence in the general population of Indonesia which is $14 \%$ according the National Health System (1984). The public health importance of low birth weight is to determine not only by the risk of subsequent morbidity and mortality but alsoby how frequently it occurs e.g.its prevalence in a given population.

The purpose to look for alternative anthropometric measurements is to be able to identify low birth weight in a given population using simple methods, this is important because more than $50 \%$ of infants are born at home attended by traditional birth attendans who are illiterate. The study try to test out anthropome- tric measurements that can be used at village level.Weighing scales for newborn infants are also not always available an alternative method have to be used to be able identify infants at risk based on their birth weight. The WHO have analyzed the multicenter study conducted in 22 countries, they found that chest circumference of 29 and 30 centimeters show high sensitivity and positive pre dictive values. ${ }^{3}$

Although the cut-off point of $29 \mathrm{~cm}$ is in general appropriate it is still recommended to test out the cut-off point for specific population as it may lead to an undesirable level of false negative diagnosis. The Indonesian study found a sensitivity of $40.4 \%$ meaning that $.59 .6 \%$ would not be diagnosed on the other hand using this cut-off point the probability of the diagnosis being correct is $67.2 \%$ The decision to use other cutoff point depends also on the health services whether they can afford to manage more cases, for instance if the cut-off point was taken lower $(<28 \mathrm{~cm})$. Considering the health services in Indonesia at present time, we assumed that it probably cannot afford high number of referrals especially when it is based only on birthweight.

Chest cirrcumference is in many instances desirable compared to arm circumference although both are reliable. Arm circumference shows the highest positive predictive value at $<9 \mathrm{~cm}$, the sensitivity is found to be $34.4 \%$ and the positive predictive value of $69.0 \%$ was highest compared to other cut-off points In the practice however chest circumference is easier to measure compared to arm circumference.
The Use of Intrauterine Growth Chart

Fetal growth chart can be used for the screening of high risk newborns at birth. A simple routine procedure, i.e. plotting the newborn weight, length, or head circumference on a fetal growth chart will tell not only whether the infant is light, appropriate, or heavy-for date, but also allows for estimation of the intrauterine environment. Fetal growth chart can also be used for extrauterine growth monitoring of preterm infants. Gestational age and head growth should be considered in following the growth of very premature infants. ${ }^{13}$

The pattern of intrauterine growth and somatic development of infants in a particular population are proven not to be static but changes with time and social condition. 'These changes, so-called secular growth changes, were first discussed at the beginning of the 19th century. Secular means during a prolonged period. Some authors used the word in the sense of "lasting a century". ${ }^{11}$ Secular growth in birth weight is widely discussed; periodic measurements of birth weight give a picture of the general health status of the population. ${ }^{2}$ Population's growth is subject to change and up to date values should be put for disposal from centers of maternal and child care.

\section{Limitation of the Study}

This study suffered from weaknesses frequently found in multicenter surveys. More seriously however was the reliability of gestational assessment which rely heavily of LMP. ${ }^{16}$ The investigators have tried to correct the excess of errors by developing a tight inclusion criteria. The use of obstretric ultrasonography for fetal anthropometry was not possible because not every center has an USG equipment.

1. From the incoming data of anthropometric measurements from several centers there was a tendency for measurements to be recorded in round numbers. As a consequence, a heaping was found at the 50 grams and 100 grams for birth weight. The survey protocol had required the survey implementators to record the data to the nearest 10 grams.

2. The survey was not successful in collecting anthropometric data of infants of low gestational age. Because of the very tight inclusion criteria many births have to be excluded from the survey. In referral hospitals many mothers have some kinds of complication during the perinatal or delivery period which result in a very large prevalence of very low birth weight infants. On the other hand it is also questionable whether low birth weight babies constitute a kealthy population. ${ }^{1}$

3. Because mother's knowledge about her exact last menstrual period was mandatory, the results showed that all infants included in the survey were born from mothers of a relatively higher educational status and from mid or upper socioea " *el.

4. The interest of each contributing center was not the same, as was expected. Unfortunately this had an impact on the quality of the study, which resulted that almost $5 \%$ of the data had to be excluded because of extreme and illogical measurements, or because of incomplete forms. 


\section{Summary and Conclusions}

The multicenter survey on newborn anthropometric measurements was conducted to have a reference curve of intrauterine growth for Indonesian newborns. So far Indonesian clinicians had always use the Denver intrauterine growth curve as reference curve

The study conducted in 14 Teaching centers reveals that:

1. Using a tight inclusion criteria only $8 \%$ of total singleton births were included, women who knows the first day of the last menstrual period were better educated and of better socioeconomic status. Therefore the results of this study represent the middle socioeconomic level of the Indonesian women.

2. Mean birth weight for boys was about 60 gram higher compared to girls, mean birth length about $0.5 \mathrm{~cm}$ longer, for head it was $0.3 \mathrm{~cm}$ greater, while for boys and girls, the mean chest circumference was significant different for arm circumference no difference was found.

3. If birth weight and birth length of the infant were cross tabulated to gestational age it shows that at 40 weeks birth weight and birth length became more stable. This was probably due to the maturity of the placenta. The same result can be seen in other studies. For every gestational age and percentiles, laterborn infants were heavier than first-born infants. Birth weight at 42 weeks gestation was lower in first-born infants, this was not shown in the later-born infants which showed higher weights for each percentile. Parity of the mother affected birth weight more than birth length Birth length became stable at 39 weeks probably due to early dysfunction of the placenta in borderline small for date in fants.

4. Arm circumference of $<9 \mathrm{~cm}$ had the highest predictive value and sensitivity, while for chest circumference the cut-off point is $<29 \mathrm{~cm}$. Chest circumference is easier to measure compare to arm circumference.

5. The Indonesian newborns had in general higher mean birthweight for gestational age 34-38 weeks compared to the Denver study, after this gestational age newborns in Denver have higher birth weights. Mean birth weight of the Denver infants differ signifantly from the mean birthweight of Indonesian middle clase newborn infants. Therefore the Denver Intrauterine growth curve cannot be used as a reference for Indonesian newborns.

\section{References}

1. Lubchenco LO, Hansman C., Dressler M. and Boyd E., Intrauterine growth as estimated from liveborn birth weight data at 24 to 42 weeks of gestation. Pediatrics 1963; 69:793-800

2. Lechtig A., Sterky $\mathrm{G}$ and Tafari $N$. In birthweight Distribution an Indicator of Social Development Sarec Report no. R:2; 1978, $87-90$

3. Diamond I, Guidotti R. The use of a simple anthropometric measurements for predicting birth weight. Child Survival, $\mathrm{Re}$ search Note Number 26 CS, 22 1969, June 2-10

4. Finstrom O. Studies on maturity in newborn infants, birthweight, crown-heel length, head circumference and skull diameter in relation to gestational age Acto Pediatr Scand 1971; 60:685-94.
5. Miller HC, Merritt TA. Fetal growth in humans. Chicago: Yearbook Medical Publisher, 1979;31-82.

6. Birth weight surrogates. The relationship between birth weight, arm and chest circumference. World Health Organization $\mathrm{MCH} / 87.8$

7. Rooth G, Meirik O, Karlberg P. Estimation of the "normal growth of swedish infants at term", Preliminary Report. Acta Pediatr Scand 1985; 319 (Suppl):76-9.

8. Petros-Barvazian, Behar M. problem identification. low birth weight-a major global problem. In: Birthweight distribution an indicator of social development. Sarec Report no. R:2, 1978., 9-15.

9. Puffer RR, Serrano CV. Patterns of birth weight, Pan American Health Organization Scientific Publication no. 504. 1987;1-9.
10. Gruenwald P, Minh HN. Evaluation of body and organ weights in perinatal pathology. J Obstet Gynec 1961; 82: 312.

11. Mc Keown T, Record RG. The influence of placental size on fetal growth in man with special reference to multiple pregniancy. $J$ Endocrinol 1953; 9:418.

12. Falkner F. Key issues in perinatal growth. Acta Pediatr Scand 1985, 319 (Suppl) : 21-5.

13. Dunn PM. A Perinatal Growth Chart for International comparison. Acta Pediatr Scand 1985; 319 (Suppl)180-7.

14. Ray Yip. Altitude and birth weight. $\mathrm{J} \mathrm{Pe}$ diatr 1987, 869-76.

15. Nishida H, Sakamoto S, Sakanoue M. New fetal growth curves for Japanese. Acta Pediatr Scand 1985; 319 (Suppl):62-7.

16. Keen DV, Pearse RG. Intrauterine growth curves: problems and limitation. Acta $\mathrm{Pe}$ diatr Scand 1985 (Suppl) 319:52-4. 


\section{ANNEX}

TABLE I

SAMPLE SIZE BY GESTATIONAL AGE

\begin{tabular}{rlrcr}
\hline & & \multicolumn{3}{c}{$\begin{array}{c}\text { Gestational age } \\
\text { (weeks) }\end{array}$} \\
\hline No & University & $\begin{array}{c}\text { No. of } \\
\text { subjects }\end{array}$ & Mean & SD \\
\hline 1 & Unsyiah & 727 & 39.75 & 1.42 \\
2 & USU & 246 & 39.96 & 1.44 \\
3 & Unand & 96 & 39.20 & 2.48 \\
4 & Unsri & 503 & 39.62 & 1.79 \\
5 & Unsrat & 402 & 39.59 & 1.99 \\
6 & Unhas & 394 & 39.94 & 1.94 \\
7 & Unair & 293 & 39.49 & 2.01 \\
8 & Unbraw & 280 & 39.83 & 2.13 \\
9 & UGM & 662 & 39.65 & 2.08 \\
10 & Undip & 678 & 39.77 & 1.95 \\
11 & UnS & 192 & 38.92 & 2.61 \\
12 & UI & 386 & 39.77 & 1.95 \\
13 & Unpad & 560 & 39.57 & 1.69 \\
14 & RSHK & 425 & 39.60 & 1.92 \\
\hline & Total & 5844 & 39.67 & 1.88 \\
\hline & & & &
\end{tabular}

TABLE ॥

SAMPLE SIZE BY ETHNIC GROUP

\begin{tabular}{clr}
\hline No & \multicolumn{1}{c}{ Ethnic Group } & \multicolumn{1}{c}{$\mathbf{n}$} \\
\hline 1 & Sumatera & 1680 \\
2 & Jawa & 3217 \\
3 & Kalimantan \& Sulawesi & $: 24$ \\
4 & Maluku & 21 \\
5 & Others & 202 \\
\hline & Total & 5844 \\
\hline
\end{tabular}


TABLE III

BIRTH WEIGHT IN PERCENTILES AND GESTATIONAL AGE FOR BOYS

\begin{tabular}{|c|c|c|c|c|c|c|c|}
\hline \multirow[t]{2}{*}{ No } & \multirow{2}{*}{$\begin{array}{c}\text { GA } \\
\text { (weeks) }\end{array}$} & \multicolumn{6}{|c|}{ Birth weight (grams) } \\
\hline & & P10 & P25 & P50 & P75 & P90 & $\mathrm{n}$ \\
\hline 1 & 34 & 1870 & 2090 & 2620 & 2990 & 3140 & 29 \\
\hline 2 & 35 & 2130 & 2500 & 2750 & 3110 & 3340 & 35 \\
\hline 3 & 36 & 2210 & 2508 & 2800 & 3213 & 3500 & 70 \\
\hline 4 & 37 & 2300 & 2555 & 2825 & 3100 & 3408 & 145 \\
\hline 5 & 38 & 2500 & 2695 & 2940 & 3200 & 3450 & 325 \\
\hline 6 & 39 & 2600 & 2820 & 3100 & 3350 & 3587 & 691 \\
\hline 7 & 40 & 2680 & 2905 & 3150 & 3480 & 3750 & 897 \\
\hline 8 & 41 & 2750 & 3000 & 3250 & 3500 & 3800 & 465 \\
\hline 9 & 42 & 2758 & 3000 & 3290 & 3600 & 3865 & 203 \\
\hline 10 & 43 & 2800 & 3000 & 3250 & 3520 & 3879 & 96 \\
\hline \multirow[t]{2}{*}{11} & 44 & 2620 & 2900 & 3100 & 3530 & 3729 & 43 \\
\hline & & & & & & & 2999 \\
\hline
\end{tabular}

TABLE IV

BIRTH WEIGHT IN PERCENTILES AND GESTATIONAL AGE FOR GIRLS

\begin{tabular}{|c|c|c|c|c|c|c|c|}
\hline \multirow[t]{2}{*}{ No } & \multirow{2}{*}{$\begin{array}{c}\text { GA } \\
\text { (weeks) }\end{array}$} & \multicolumn{6}{|c|}{ Birth weight (grams) } \\
\hline & & P10 & P25 & P50 & P75 & P90 & $\mathrm{n}$ \\
\hline 1 & 34 & 2055 & 2200 & 2445 & 2800 & 3300 & 14 \\
\hline 2 & 35 & 1976 & 2200 & 2655 & 2980 & 3210 & 35 \\
\hline 3 & 36 & 2285 & 2600 & 2800 & 3200 & 3430 & 66 \\
\hline 4 & 37 & 2298 & 2525 & 2750 & 3025 & 3288 & 117 \\
\hline 5 & 38 & 2373 & 2600 & 2850 & 3100 & 3336 & 240 \\
\hline 6 & 39 & 2600 & 2750 & 3000 & 3291 & 3500 & 618 \\
\hline 7 & 40 & 2650 & 2870 & 3100 & 3315 & 3600 & 813 \\
\hline 8 & 41 & 2632 & 2882 & 3100 & 3400 & 3706 & 497 \\
\hline 9 & 42 & 2700 & 2880 & 3120 & 3400 & 3700 & 243 \\
\hline 10 & 43 & 2870 & 3000 & 3200 & 3440 & 3830 & 84 \\
\hline \multirow[t]{2}{*}{11} & 44 & 2652 & 2850 & 3200 & 3500 & 3780 & 31 \\
\hline & & & & & & & 2758 \\
\hline
\end{tabular}




\section{TABLE V}

BIRTH WEIGHT INPERCENTILES AND GESTATIONAL AGE FOR BOTH SEXES

\begin{tabular}{|c|c|c|c|c|c|c|c|}
\hline \multirow[t]{2}{*}{ No } & \multirow{2}{*}{$\begin{array}{c}\text { GA } \\
\text { (weeks) }\end{array}$} & \multicolumn{6}{|c|}{ Birth weight (grams) } \\
\hline & & P10 & P25 & P50 & P75 & P90 & n \\
\hline 1 & 34 & 1924 & 2150 & 2580 & 2950 & 3124 & 43 \\
\hline 2 & 35 & 2005 & 2400 & 2705 & 3000 & 3290 & 70 \\
\hline 3 & 36 & 2285 & 2543 & 2800 & 3200 & 3500 & 136 \\
\hline 4 & 37 & 2300 & 2548 & 2800 & 3053 & 3350 & 262 \\
\hline 5 & 38 & 2450 & 2645 & 2900 & 3155 & 3400 & 565 \\
\hline 6 & 39 & 2600 & 2800 & 3050 & 3300 & 3520 & 1309 \\
\hline 7 & 40 & 2650 & 2900 & 3100 & 3400 & 3694 & 1710 \\
\hline 8 & 41 & 2700 & 2904 & 3200 & 3483 & 3767 & 962 \\
\hline 9 & 42 & 2707 & 2929 & 3200 & 3500 & 3800 & 446 \\
\hline 10 & 43 & 2803 & 3000 & 3205 & 3500 & 3840 & 180 \\
\hline \multirow[t]{2}{*}{11} & 44 & 2645 & 2900 & 3175 & 3505 & 3725 & 74 \\
\hline & & & & & & & 5,757 \\
\hline
\end{tabular}

TABLE VI

BIRTH LENGTH IN PERCENTILES AND GESTATIONAL AGE FOR BOYS

\begin{tabular}{rccccccc}
\hline No & $\begin{array}{c}\text { GA } \\
\text { (weeks) }\end{array}$ & \multicolumn{6}{c}{ Birth length (cm) } \\
\cline { 3 - 8 } & & P10 & P25 & P50 & P75 & P90 & n \\
\hline 1 & 34 & 43 & 43 & 46 & 49 & 49 & 29 \\
2 & 35 & 45 & 47 & 48 & 50 & 51 & 35 \\
3 & 36 & 45 & 47 & 49 & 50 & 51 & 70 \\
4 & 37 & 46 & 47 & 48 & 50 & 51 & 145 \\
5 & 38 & 46 & 47 & 49 & 50 & 51 & 325 \\
6 & 39 & 47 & 48 & 50 & 50 & 51 & 691 \\
7 & 40 & 48 & 49 & 50 & 51 & 52 & 897 \\
8 & 41 & 47 & 49 & 50 & 51 & 52 & 465 \\
9 & 42 & 48 & 49 & 50 & 51 & 52 & 203 \\
10 & 43 & 48 & 49 & 50 & 51 & 52 & 96 \\
11 & 44 & 47 & 49 & 50 & 51 & 52 & 43 \\
\hline
\end{tabular}


TABLE VII

BIRTH LENGTH IN PERCENTILES AND GESTATIONAL AGE FOR GIRLS

\begin{tabular}{rccccccc}
\hline No & GA & \multicolumn{6}{c}{ Birth length (cm) } \\
\cline { 3 - 8 } & (weeks) & P10 & P25 & P50 & P75 & P90 & n \\
\hline 1 & 34 & 42 & 45 & 48 & 50 & 52 & 14 \\
2 & 35 & 43 & 45 & 47 & 49 & 50 & 35 \\
3 & 36 & 46 & 47 & 49 & 50 & 51 & 66 \\
4 & 37 & 46 & 47 & 48 & 50 & 50 & 117 \\
5 & 38 & 46 & 47 & 48 & 49 & 50 & 240 \\
6 & 39 & 46 & 48 & 49 & 50 & 51 & 618 \\
7 & 40 & 47 & 48 & 49 & 50 & 51 & 813 \\
8 & 41 & 47 & 48 & 49 & 50 & 51 & 497 \\
9 & 42 & 47 & 48 & 50 & 50 & 52 & 243 \\
10 & 43 & 48 & 49 & 50 & 51 & 51 & 84 \\
11 & 44 & 48 & 49 & 50 & 51 & 52 & 31 \\
\hline
\end{tabular}

TABLE VIII

BIRTH LENGTH IN PERCENTILES AND GESTATIONAL AGE FOR BOTH SEXES

\begin{tabular}{rccccccc}
\hline No & GA & \multicolumn{6}{c}{ Birth length (cm) } \\
\cline { 3 - 7 } & (weeks) & P10 & P25 & P50 & P75 & P90 & \multicolumn{1}{c}{ n } \\
\hline 1 & 34 & 42 & 45 & 47 & 49 & 51 & 43 \\
2 & 35 & 44 & 46 & 47 & 49 & 51 & 70 \\
3 & 36 & 46 & 47 & 49 & 50 & 51 & 136 \\
4 & 37 & 46 & 47 & 48 & 50 & 51 & 262 \\
5 & 38 & 46 & 47 & 49 & 50 & 51 & 565 \\
6 & 39 & 47 & 48 & 49 & 50 & 51 & 1,309 \\
7 & 40 & 47 & 48 & 50 & 50 & 51 & 1,710 \\
8 & 41 & 47 & 48 & 50 & 51 & 52 & 962 \\
9 & 42 & 47 & 48 & 50 & 51 & 52 & 446 \\
10 & 43 & 48 & 49 & 50 & 51 & 52 & 180 \\
11 & 44 & 48 & 49 & 50 & 51 & 52 & 74 \\
\hline
\end{tabular}


TABLE IX

HEAD CIRCUMFERENCE IN PERCENTILES AND GESTATIONAL AGE FOR BOYS

\begin{tabular}{rccccccc}
\hline No & GA & \multicolumn{6}{c}{ Head circumference $(\mathrm{cm})$} \\
\cline { 3 - 8 } & (weeks) & P10 & P25 & P50 & P75 & P90 & n \\
\hline 1 & 34 & 30 & 31 & 33 & 34 & 34 & 29 \\
2 & 35 & 30 & 32 & 33 & 34 & 36 & 35 \\
3 & 36 & 30 & 32 & 33 & 34 & 35 & 70 \\
4 & 37 & 31 & 32 & 33 & 34 & 35 & 145 \\
5 & 38 & 32 & 32 & 33 & 34 & 35 & 325 \\
6 & 39 & 32 & 33 & 34 & 35 & 35 & 691 \\
7 & 40 & 32 & 33 & 34 & 35 & 36 & 897 \\
8 & 41 & 32 & 33 & 34 & 35 & 36 & 465 \\
9 & 42 & 32 & 33 & 34 & 35 & 36 & 203 \\
10 & 43 & 32 & 33 & 34 & 35 & 36 & 96 \\
11 & 44 & 32 & 33 & 34 & 35 & 36 & 43 \\
\hline
\end{tabular}

\section{TABLE $X$}

HEAD CIRCUMFERENCE IN PERCENTILES AND GESTATIONAL AGE FOR GIRLS

\begin{tabular}{rccccccc}
\hline No & GA & \multicolumn{6}{c}{ Head circumference $(\mathrm{cm})$} \\
\cline { 3 - 8 } & (weeks) & P10 & P25 & P50 & P75 & P90 & n \\
\hline 1 & 34 & 31 & 31 & 32 & 33 & 35 & 14 \\
2 & 35 & 30 & 31 & 32 & 33 & 34 & 35 \\
3 & 36 & 31 & 32 & 33 & 34 & 35 & 66 \\
4 & 37 & 31 & 32 & 33 & 34 & 35 & 117 \\
5 & 38 & 31 & 32 & 33 & 34 & 35 & 240 \\
6 & 39 & 32 & 33 & 33 & 34 & 35 & 618 \\
7 & 40 & 32 & 33 & 33 & 34 & 35 & 813 \\
8 & 41 & 32 & 33 & 34 & 35 & 36 & 497 \\
9 & 42 & 32 & 33 & 34 & 35 & 36 & 243 \\
10 & 43 & 32 & 33 & 34 & 35 & 36 & 84 \\
11 & 44 & 32 & 33 & 34 & 35 & 36 & 31 \\
\hline
\end{tabular}


TABLE XI

HEAD CIRCUMFERENCE IN PERCENTILES AND GESTATIONAL AGE FOR BOTH SEXES

\begin{tabular}{rcrrrrrr}
\hline No & GA & \multicolumn{6}{c}{ Head circumference $(\mathrm{cm})$} \\
\cline { 3 - 8 } & (weeks) & P10 & P25 & P50 & P75 & P90 & \multicolumn{1}{c}{ n } \\
\hline 1 & 34 & 30 & 31 & 32 & 34 & 35 & 43 \\
2 & 35 & 31 & 32 & 33 & 34 & 35 & 70 \\
3 & 36 & 30 & 32 & 33 & 34 & 35 & 136 \\
4 & 37 & 31 & 32 & 33 & 34 & 35 & 262 \\
5 & 38 & 32 & 32 & 33 & 34 & 35 & 565 \\
6 & 39 & 32 & 33 & 34 & 34 & 35 & 1309 \\
7 & 40 & 32 & 33 & 34 & 35 & 36 & 1710 \\
8 & 41 & 32 & 33 & 34 & 35 & 36 & 962 \\
9 & 42 & 32 & 33 & 34 & 35 & 36 & 446 \\
10 & 43 & 32 & 33 & 34 & 35 & 36 & 180 \\
11 & 44 & 32 & 33 & 34 & 35 & 36 & 74 \\
\hline & & & & & & & 5,757 \\
\hline
\end{tabular}


TABLE XII

CHEST CIRCUMFERENCE IN PERCENTILES AND GESTATIONAL AGE FOR BOYS

\begin{tabular}{rcrrrrrr}
\hline No & GA & \multicolumn{6}{c}{ Chest circumference $(\mathrm{cm})$} \\
\cline { 3 - 8 } & (weeks) & P10 & P25 & P50 & P75 & P90 & \multicolumn{1}{c}{ n } \\
\hline 1 & 34 & 27 & 28 & 30 & 33 & 35 & 29 \\
2 & 35 & 28 & 30 & 32 & 33 & 34 & 35 \\
3 & 36 & 29 & 30 & 32 & 33 & 34 & 70 \\
4 & 37 & 29 & 30 & 32 & 33 & 34 & 145 \\
5 & 38 & 30 & 31 & 32 & 33 & 34 & 325 \\
6 & 39 & 30 & 32 & 32 & 34 & 35 & 691 \\
7 & 40 & 31 & 32 & 33 & 34 & 35 & 897 \\
8 & 41 & 31 & 32 & 33 & 34 & 36 & 465 \\
9 & 42 & 31 & 32 & 33 & 35 & 36 & 203 \\
10 & 43 & 31 & 32 & 33 & 34 & 35 & 96 \\
11 & 44 & 31 & 32 & 33 & 34 & 35 & 43 \\
\hline
\end{tabular}




\section{TABLE XIII}

CHEST CIRCUMFERENCE IN PERCENTILES AND GESTATIONAL AGE FOR GIRLS

\begin{tabular}{rcrrrrrr}
\hline No & GA & \multicolumn{6}{c}{ Chest circumference $(\mathrm{cm})$} \\
\cline { 3 - 8 } & (weeks) & P10 & P25 & P50 & P75 & P90 & n \\
\hline 1 & 34 & 27 & 29 & 31 & 32 & 35 & 14 \\
2 & 35 & 28 & 29 & 32 & 33 & 33 & 35 \\
3 & 36 & 28 & 30 & 32 & 33 & 34 & 66 \\
4 & 37 & 29 & 30 & 32 & 33 & 34 & 117 \\
5 & 38 & 30 & 31 & 32 & 33 & 34 & 240 \\
6 & 39 & 30 & 32 & 32 & 34 & 35 & 618 \\
7 & 40 & 31 & 32 & 33 & 34 & 35 & 813 \\
8 & 41 & 31 & 32 & 33 & 34 & 35 & 497 \\
9 & 42 & 31 & 32 & 33 & 34 & 35 & 243 \\
10 & 43 & 32 & 32 & 33 & 34 & 35 & 84 \\
11 & 44 & 30 & 32 & 33 & 34 & 35 & 31 \\
\hline & & & & & & & 2758 \\
\hline
\end{tabular}

\section{TABLE XIV}

CHEST CIRCUMFERENCE IN PERCENTILES AND GESTATIONAL AGE FOR BOTH SEXES

\begin{tabular}{rcrrrrrr}
\hline No & GA & \multicolumn{6}{c}{ Chest circumference $(\mathrm{cm})$} \\
\cline { 3 - 8 } & (weeks) & P10 & P25 & P50 & P75 & P90 & \multicolumn{1}{c}{$\mathbf{n}$} \\
\hline 1 & 34 & 27 & 29 & 30 & 33 & 34 & 43 \\
2 & 35 & 28 & 30 & 32 & 33 & 34 & 70 \\
3 & 36 & 29 & 30 & 32 & 33 & 34 & 136 \\
4 & 37 & 29 & 30 & 32 & 33 & 34 & 262 \\
5 & 38 & 30 & 31 & 32 & 33 & 34 & 565 \\
6 & 39 & 30 & 32 & 32 & 34 & 34 & 1309 \\
7 & 40 & 31 & 32 & 33 & 34 & 35 & 1710 \\
8 & 41 & 31 & 32 & 33 & 34 & 35 & 962 \\
9 & 42 & 31 & 32 & 33 & 34 & 35 & 446 \\
10 & 43 & 31 & 32 & 33 & 34 & 35 & 180 \\
11 & 44 & 31 & 32 & 33 & 34 & 35 & 74 \\
\hline
\end{tabular}


TABLE XV

ARM CIRCUMFERENCE IN PERCENTILES AND GESTATIONAL AGE FOR BOYS

\begin{tabular}{|c|c|c|c|c|c|c|c|}
\hline \multirow[t]{2}{*}{ No } & \multirow{2}{*}{$\begin{array}{c}\text { GA } \\
\text { (weeks) }\end{array}$} & \multicolumn{6}{|c|}{ Arm circumference $(\mathrm{cm})$} \\
\hline & & P10 & P25 & P50 & P75 & P90 & $\mathbf{n}$ \\
\hline 1 & 34 & 8 & 9 & 10 & 11 & 12 & 29 \\
\hline 2 & 35 & 9 & 10 & 11 & 11 & 12 & 35 \\
\hline 3 & 36 & 9 & 10 & 11 & 11 & 12 & 70 \\
\hline 4 & 37 & 9 & 10 & 11 & 11 & 12 & 145 \\
\hline 5 & 38 & 9 & 10 & 11 & 11 & 12 & 325 \\
\hline 6 & 39 & 10 & 10 & 11 & 12 & 12 & 691 \\
\hline 7 & 40 & 10 & 10 & 11 & 12 & 12 & 897 \\
\hline 8 & 41 & 10 & 11 & 11 & 12 & 12 & 465 \\
\hline 9 & 42 & 10 & 11 & 11 & 12 & 12 & 203 \\
\hline 10 & 43 & 10 & 11 & 11 & 12 & 12 & 96 \\
\hline \multirow[t]{2}{*}{11} & 44 & 10 & 10 & 11 & 11 & 12 & 43 \\
\hline & & & & & & & 2999 \\
\hline
\end{tabular}

\section{TABLE XVI}

ARM CIRCUMFERENCE IN PERCENTILES AND GESTATIONAL AGE FOR GIRLS

\begin{tabular}{rccccccc}
\hline No & GA & \multicolumn{6}{c}{ Arm circumference $(\mathrm{cm})$} \\
\cline { 3 - 8 } (weeks) & P10 & P25 & P50 & P75 & P90 & n \\
\hline 1 & 34 & 8 & 9 & 10 & 11 & 12 & 14 \\
2 & 35 & 8 & 9 & 10 & 11 & 12 & 35 \\
3 & 36 & 9 & 10 & 11 & 11 & 12 & 66 \\
4 & 37 & 9 & 10 & 11 & 11 & 12 & 117 \\
5 & 38 & 9 & 10 & 11 & 11 & 12 & 240 \\
6 & 39 & 10 & 10 & 11 & 11 & 12 & 618 \\
7 & 40 & 10 & 10 & 11 & 12 & 12 & 813 \\
8 & 41 & 10 & 10 & 11 & 12 & 12 & 497 \\
9 & 42 & 10 & 10 & 11 & 12 & 12 & 243 \\
10 & 43 & 10 & 11 & 11 & 12 & 13 & 84 \\
11 & 44 & 10 & 10 & 11 & 12 & 12 & 31 \\
\hline
\end{tabular}




\section{TABLE XVII}

ARM CIRCUMFERENCE IN PERCENTILES AND GESTATIONAL AGE FOR BOTH SEXES

\begin{tabular}{rcrrrrrr}
\hline No & $\begin{array}{c}\text { GA } \\
\text { (weeks) }\end{array}$ & P10 & P25 & P50 & P75 & P90 & n \\
\hline 1 & 34 & 8.220 & 9.000 & 10.000 & 11.000 & 11.340 & 43 \\
2 & 35 & 8.500 & 9.000 & 10.050 & 11.000 & 11.500 & 70 \\
3 & 36 & 9.000 & 9.500 & 10.500 & 11.075 & 12.000 & 136 \\
4 & 37 & 9.000 & 9.875 & 10.500 & 11.100 & 12.000 & 262 \\
5 & 38 & 9.000 & 9.800 & 10.600 & 11.200 & 12.000 & 565 \\
6 & 39 & 9.600 & 10.000 & 11.000 & 11.500 & 12.000 & 1309 \\
7 & 40 & 9.800 & 10.275 & 11.000 & 11.500 & 12.000 & 1710 \\
8 & 41 & 9.800 & 10.300 & 11.000 & 11.925 & 12.000 & 962 \\
9 & 42 & 9.800 & 10.300 & 11.000 & 11.600 & 12.000 & 446 \\
10 & 43 & 10.000 & 10.500 & 11.000 & 11.750 & 12.500 & 180 \\
11 & 44 & 10.000 & 10.000 & 11.000 & 11.350 & 12.000 & 74 \\
\hline & & & & & & & 5757 \\
\hline
\end{tabular}

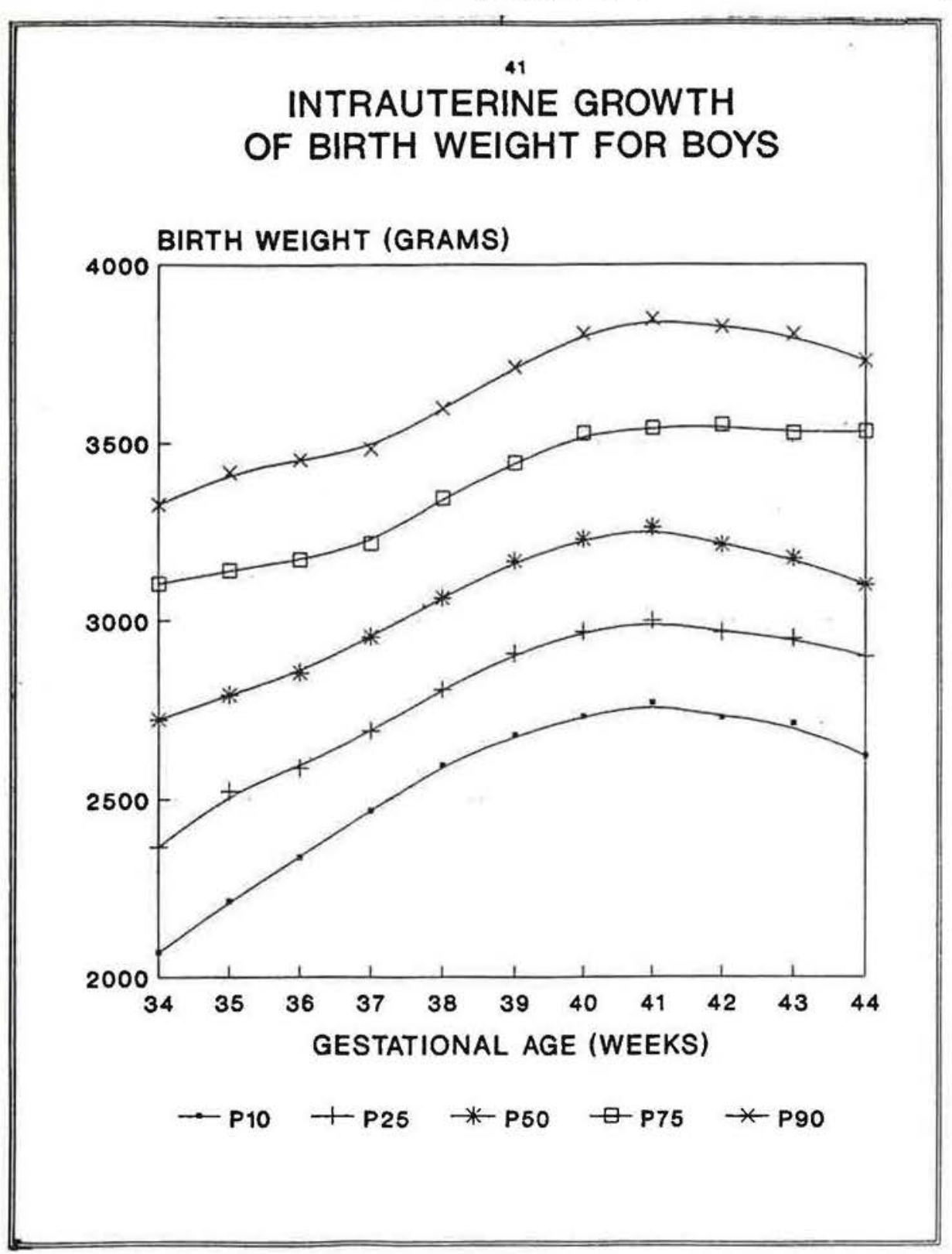

Figure 1 
INTRAUTERINE GROWTH OF BIRTH WEIGHT FOR GIRLS

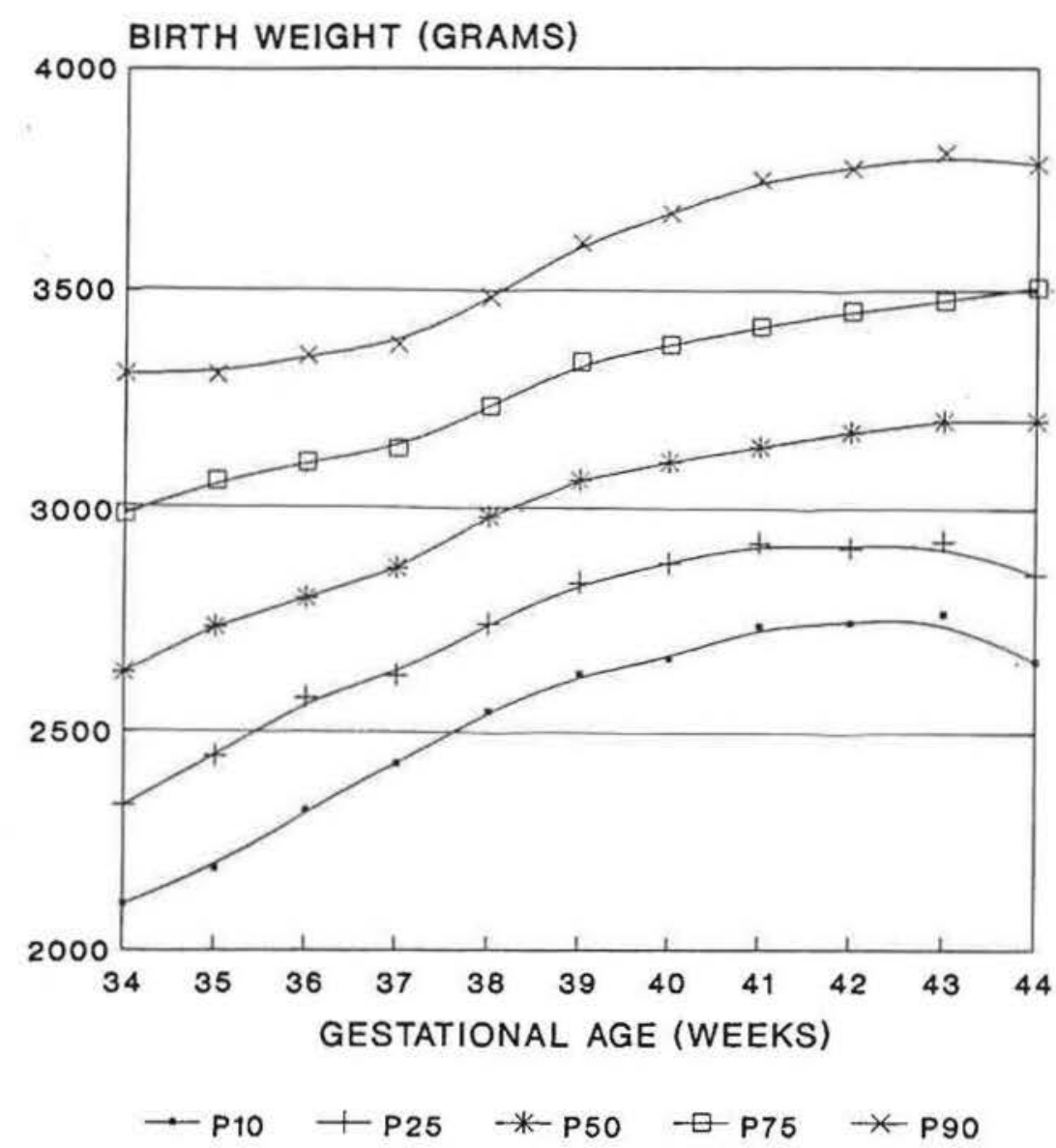

INTRAUTERINE GROWTH OF BIRTH WEIGHT FOR BOTH SEXES

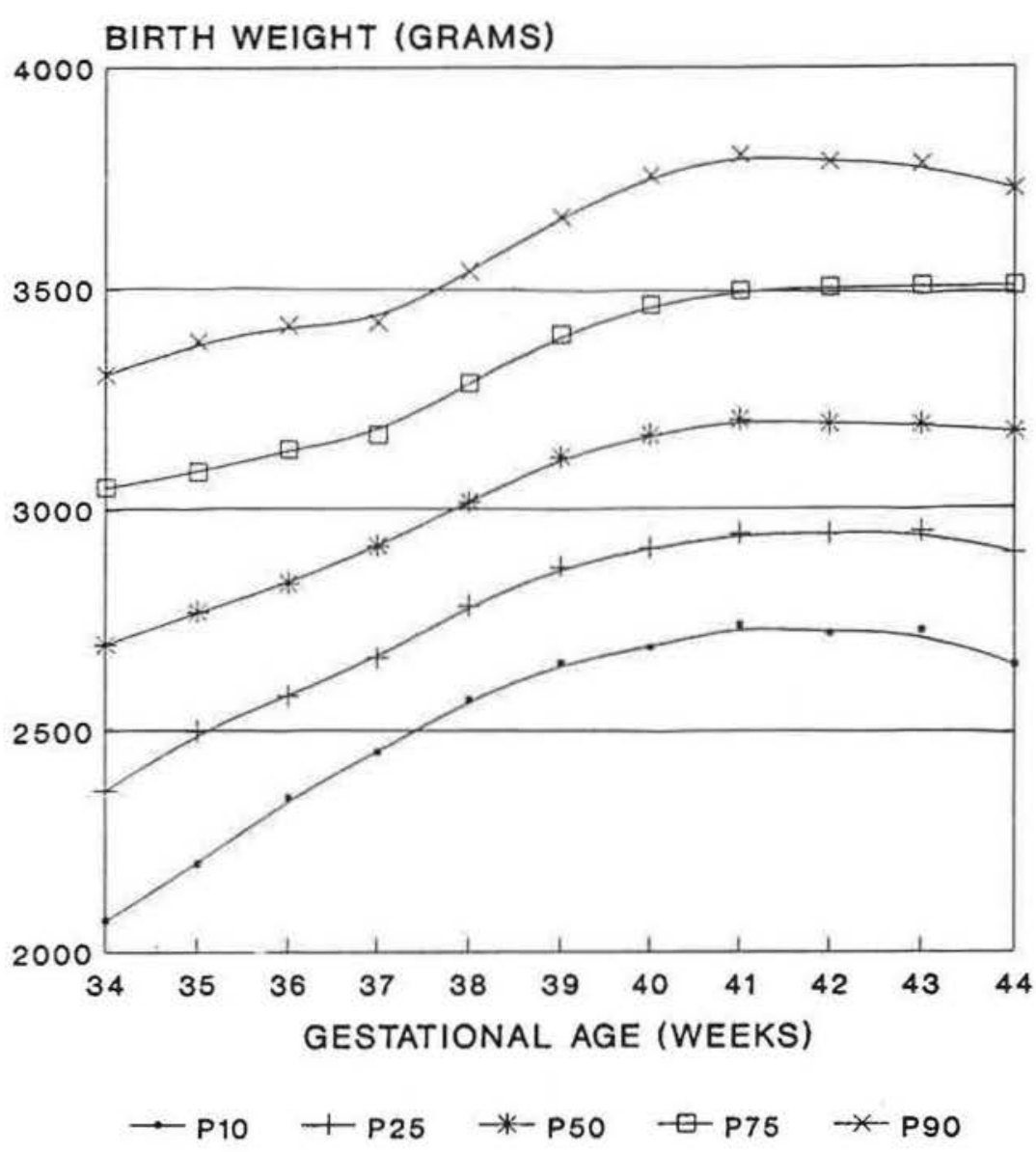

Figure 2

Figure 3 


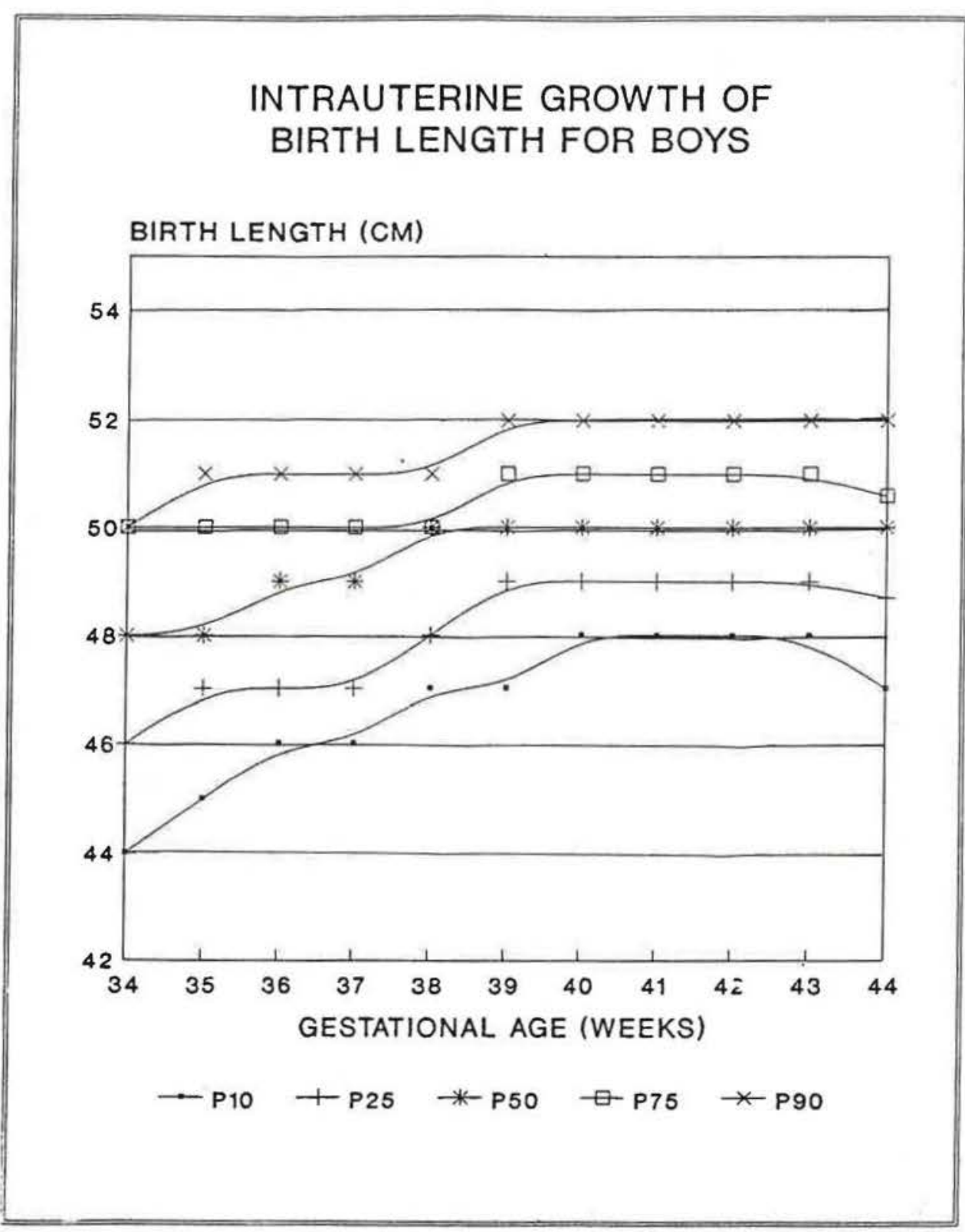

Figure 4

\section{INTRAUTERINE GROWTH OF BIRTH LENGTH FOR GIRLS}

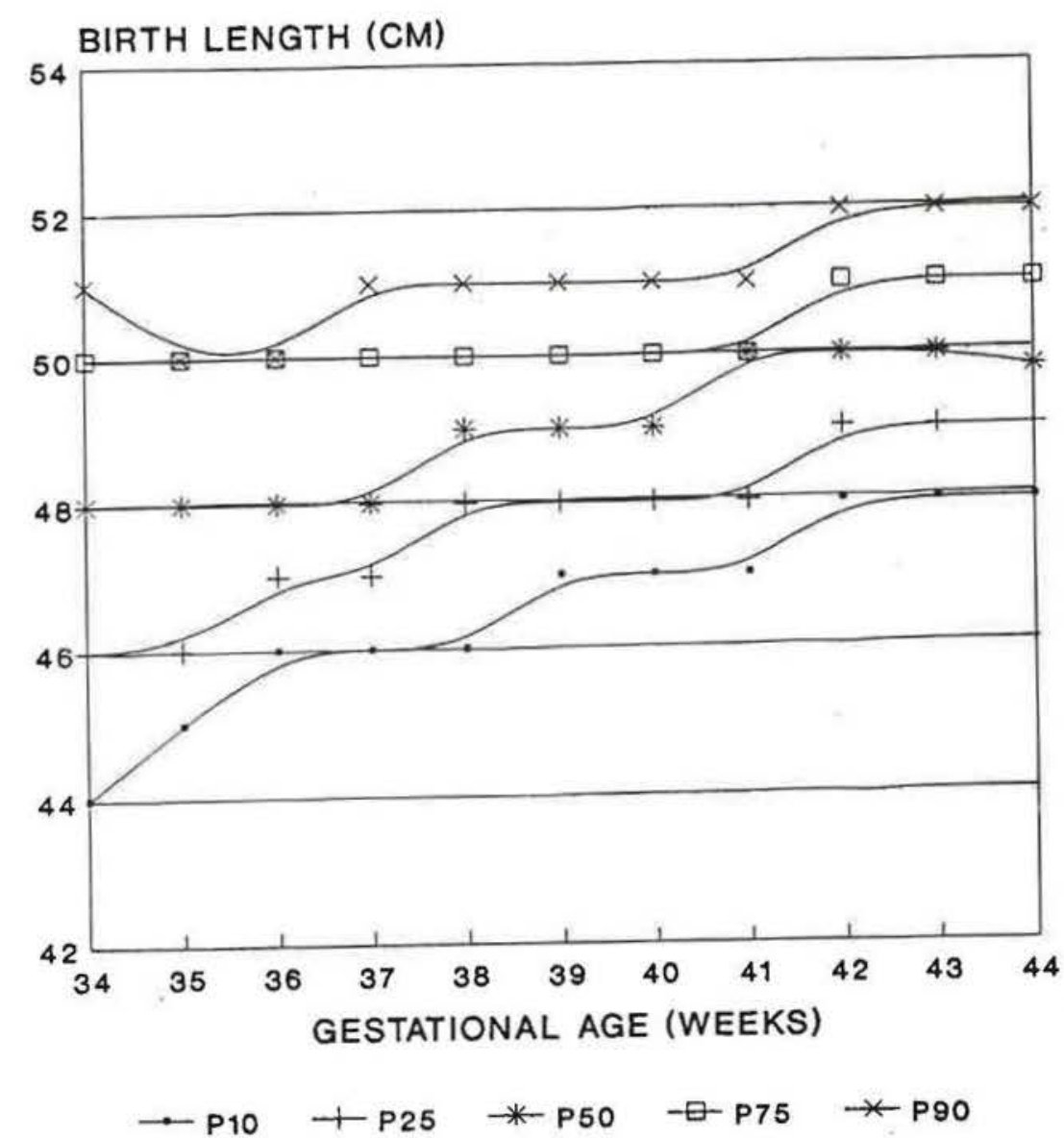

Figure 5 


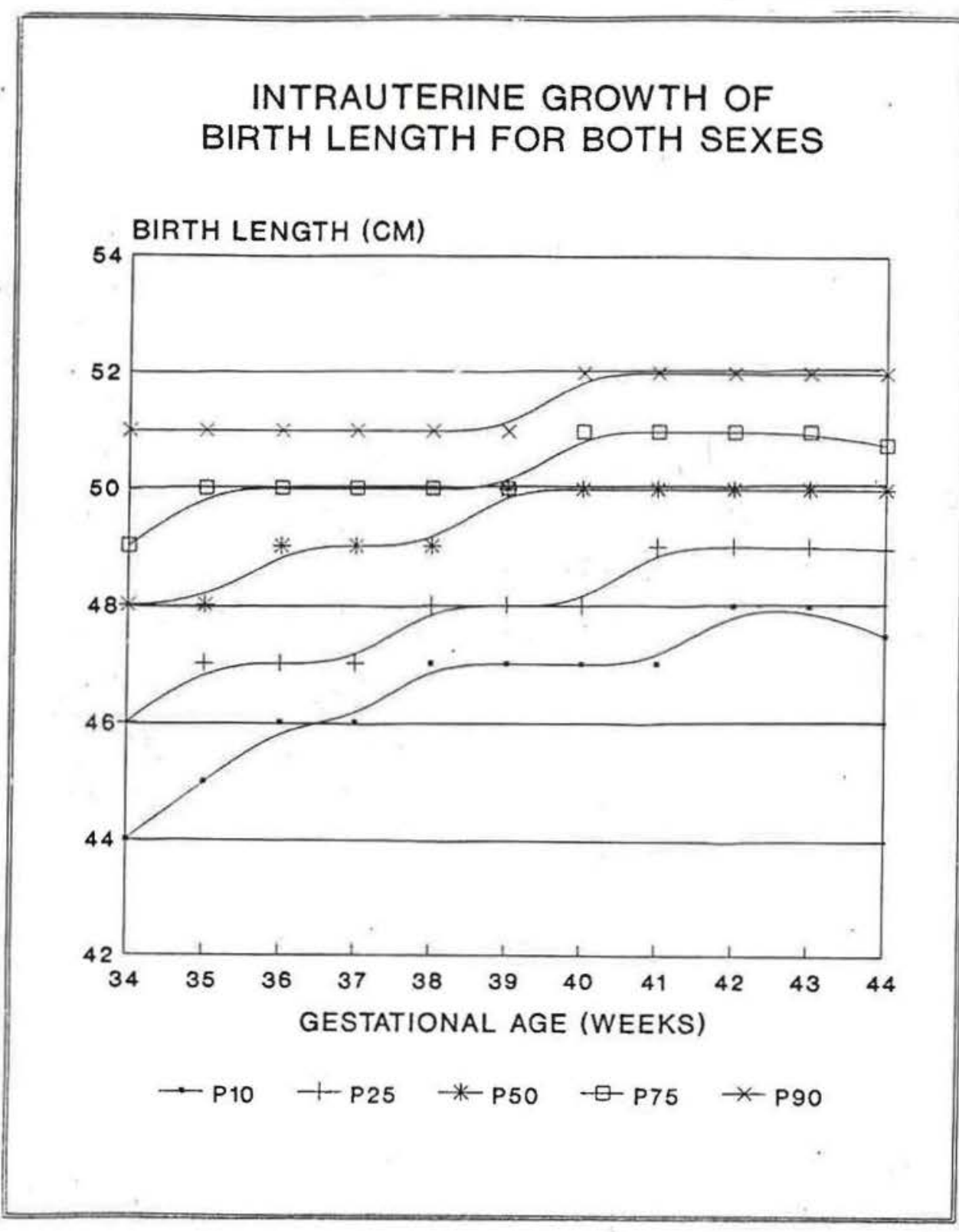

Figure 6

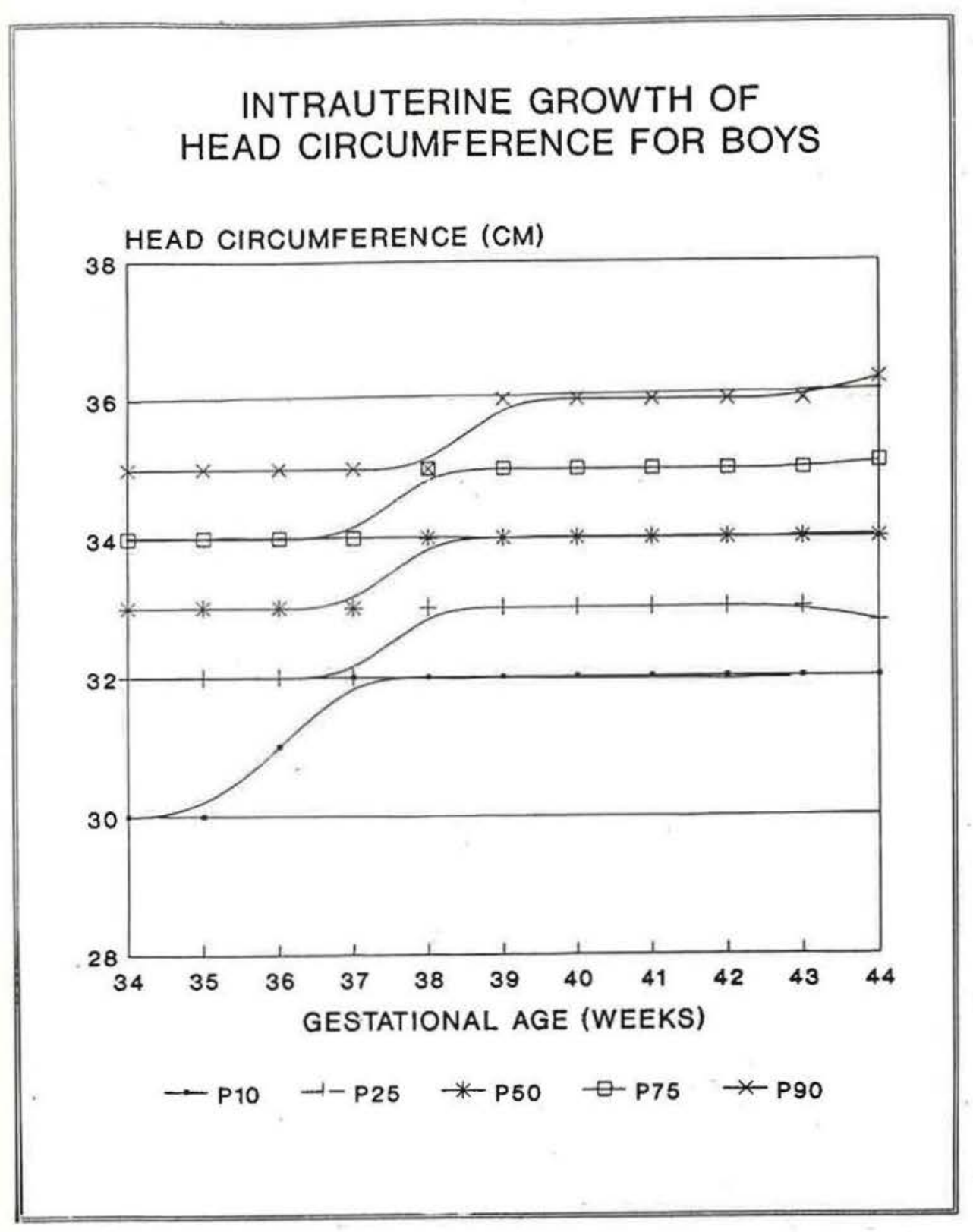

Figure 7 
INTRAUTERINE GROWTH OF HEAD CIRCUMFERENCE FOR GIRLS

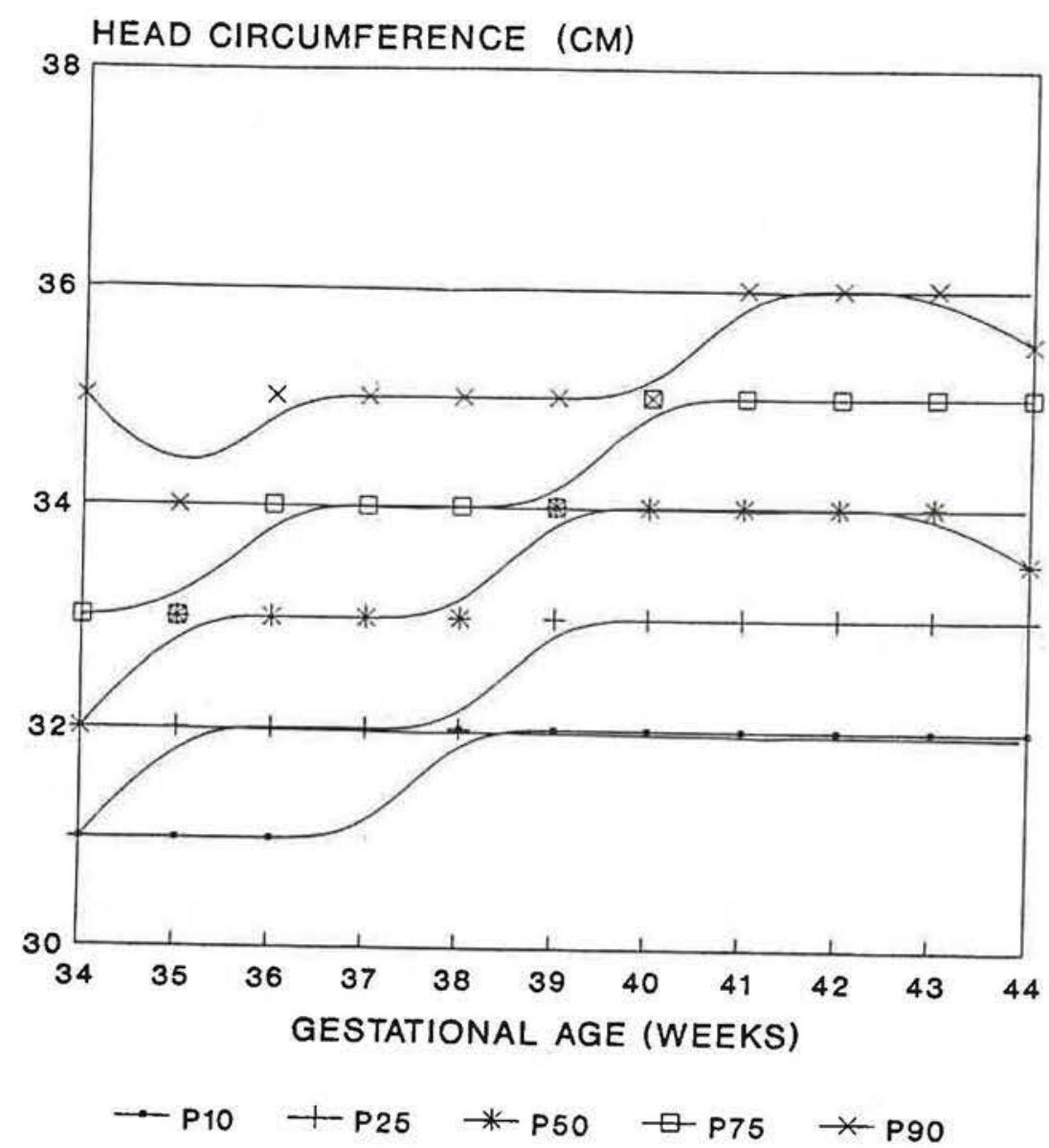

INTRAUTERINE GROWTH OF HEAD CIRCUMFERENCE FOR BOTH SEXES

HEAD CIRCUMFERENCE (CM)

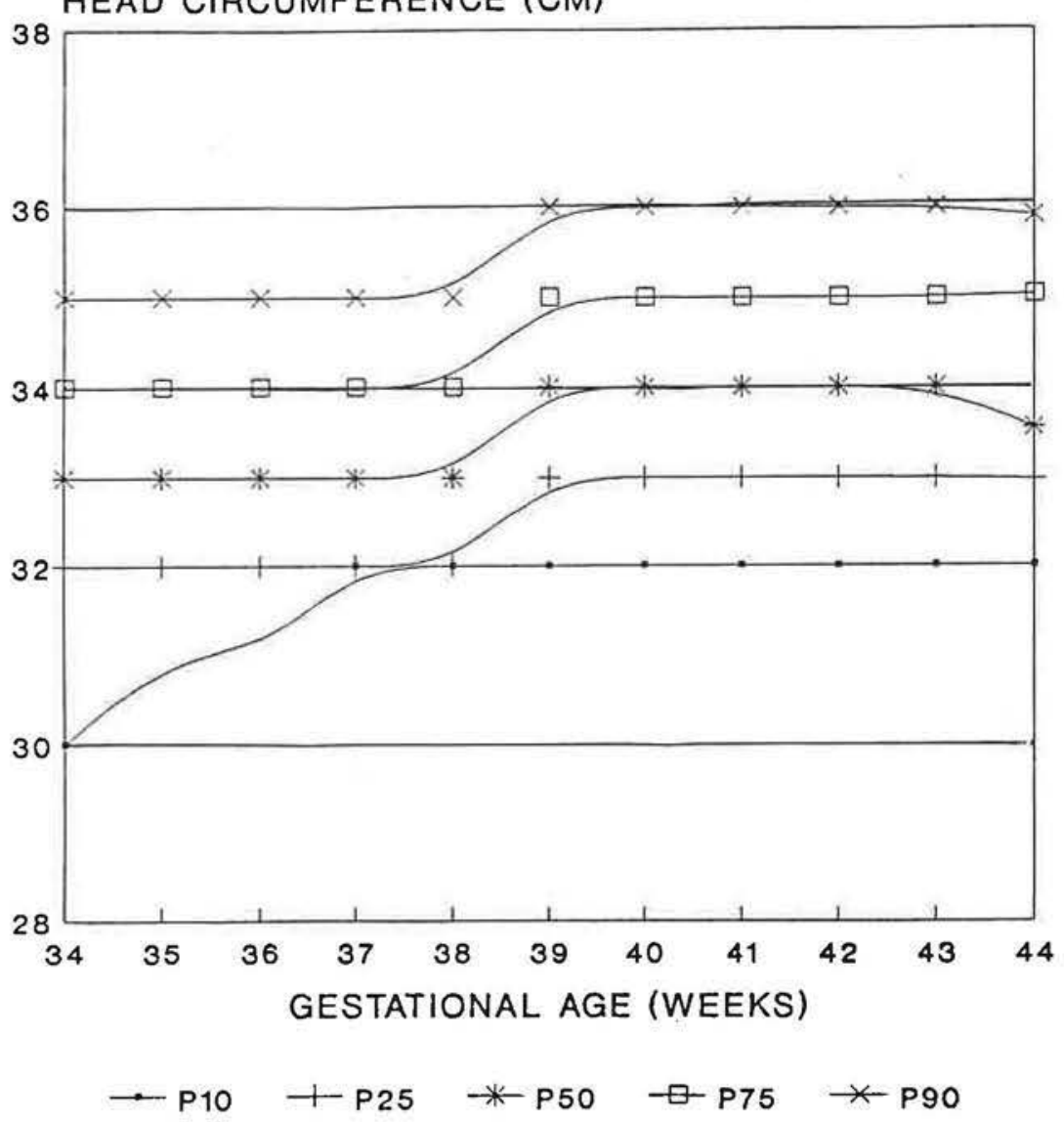


INTRAUTERINE GROWTH OF CHEST CIRCUMFERENCE FOR BOYS

\section{CHEST CIRCUMFERENCE (CM)}

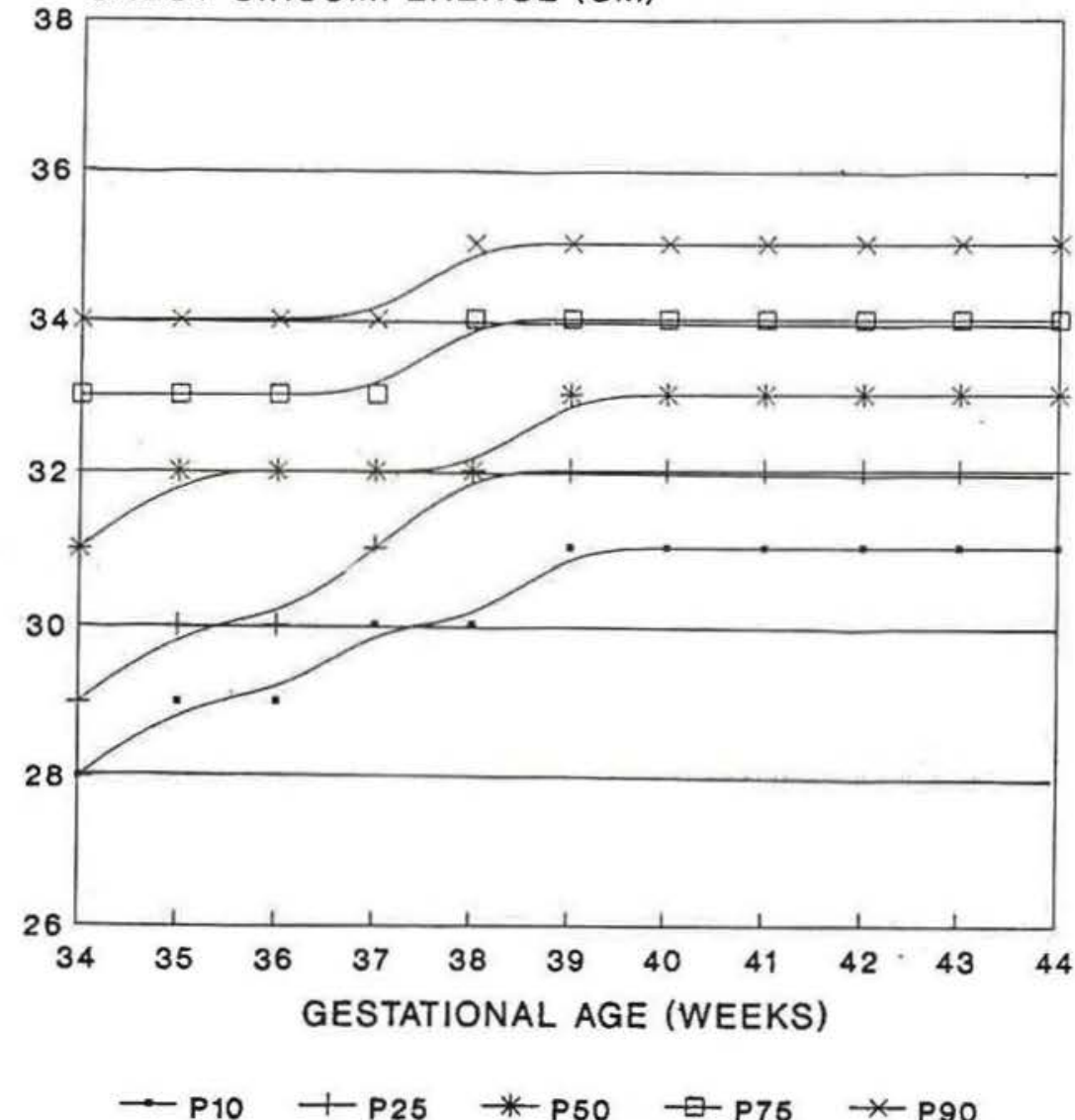

INTRAUTERINE GROWTH OF CHEST CIRCUMFERENCE FOR GIRLS

CHEST CIRCUMFERENCE (CM)

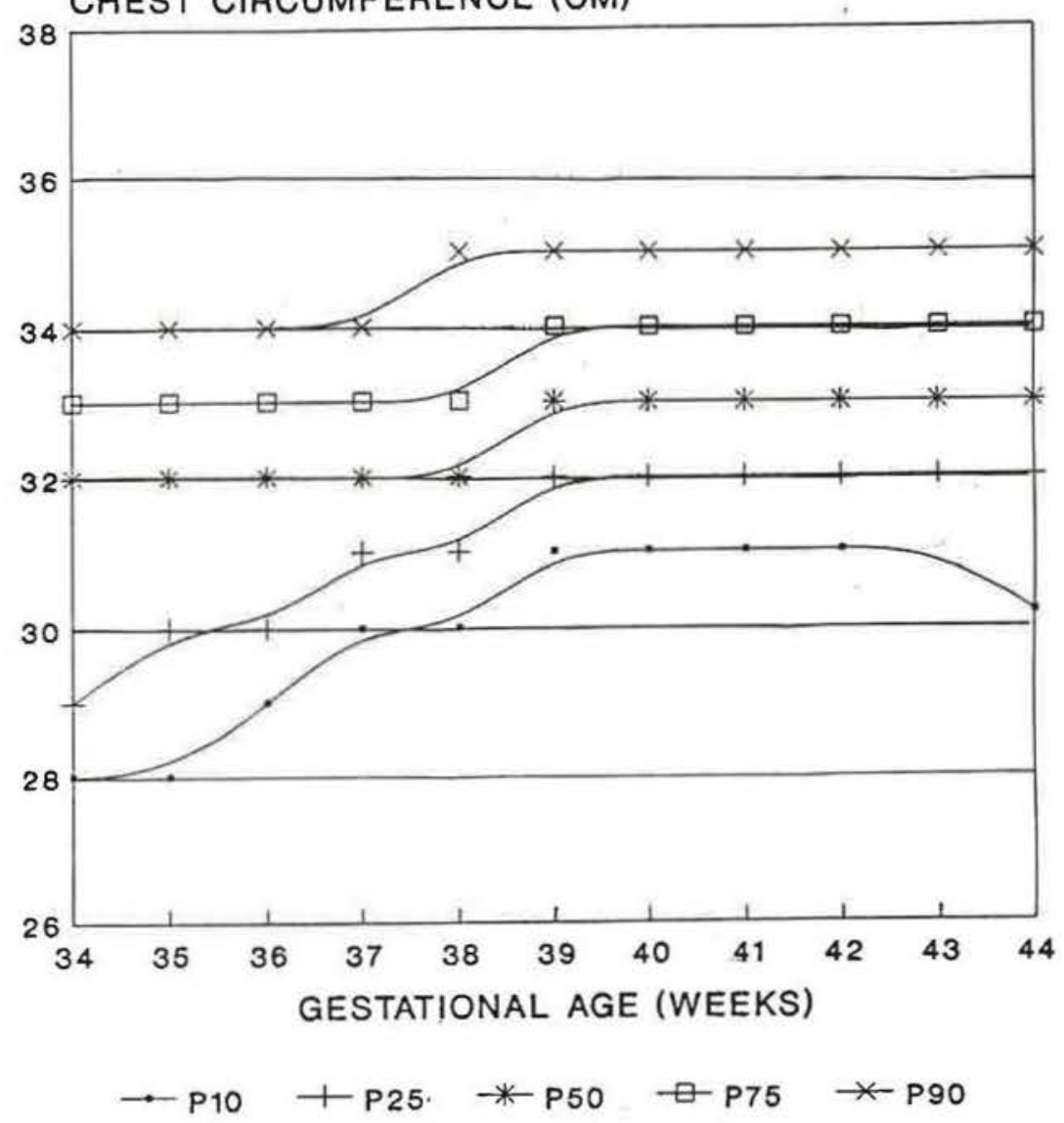



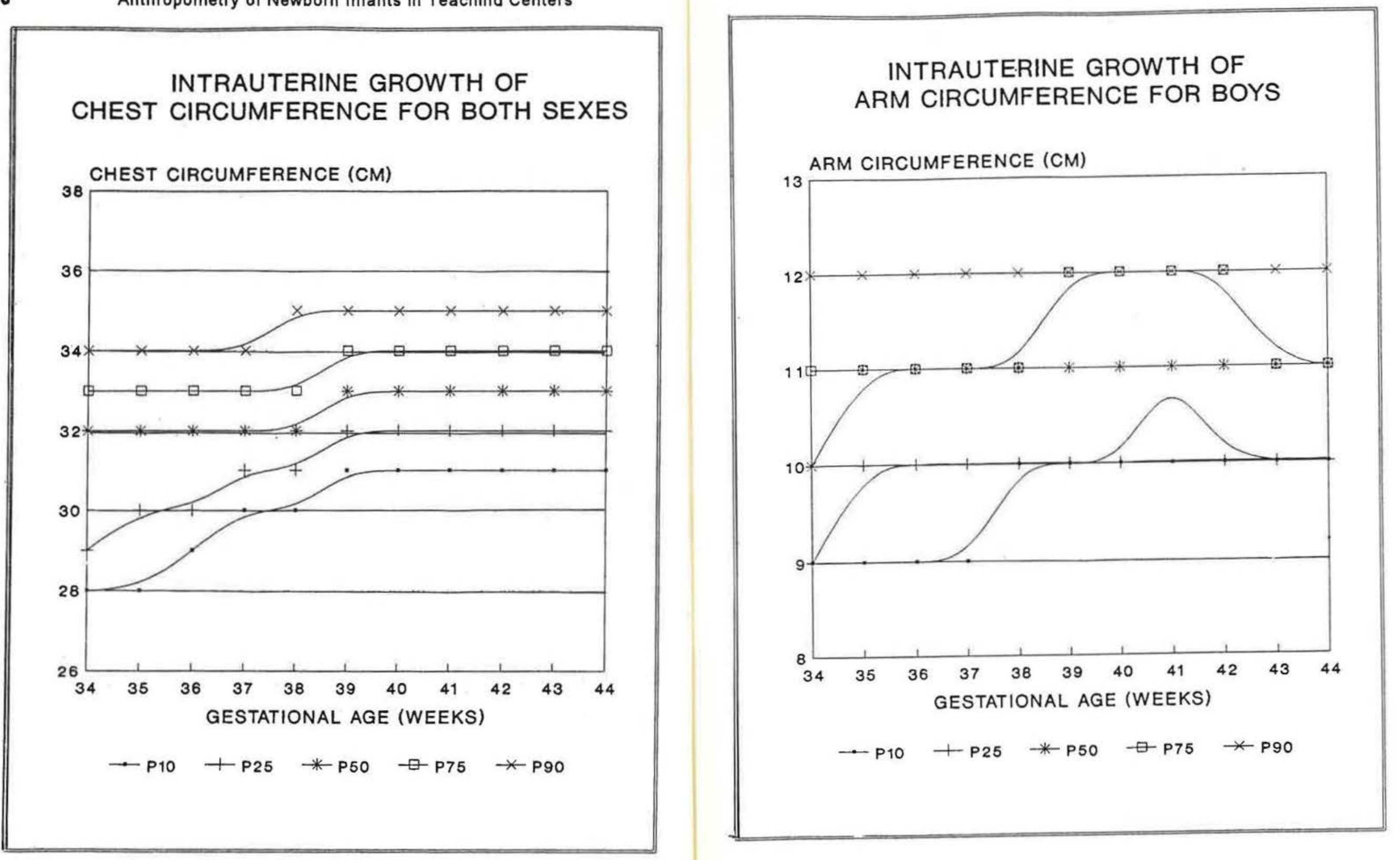

Figure 12 

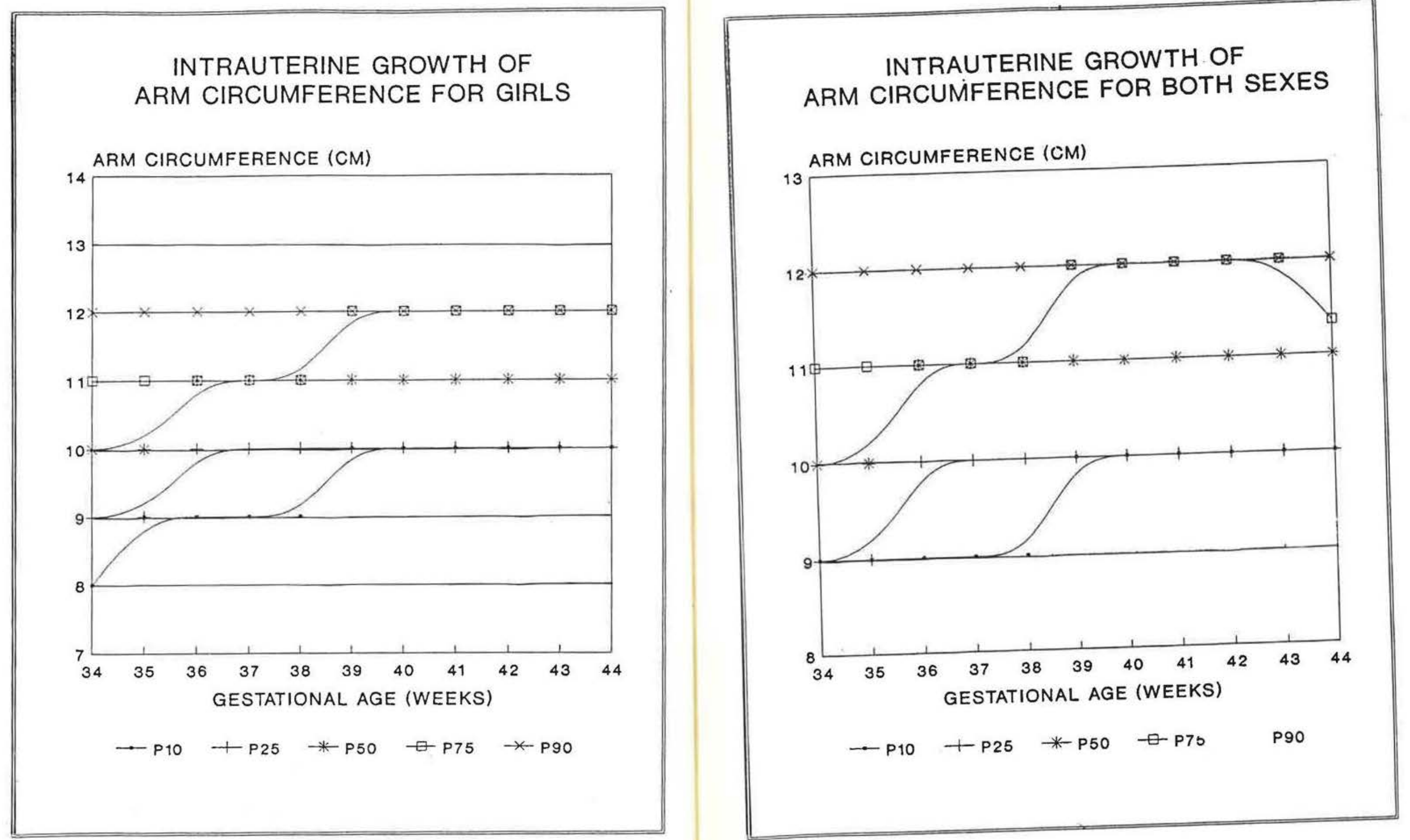

Figure 14 


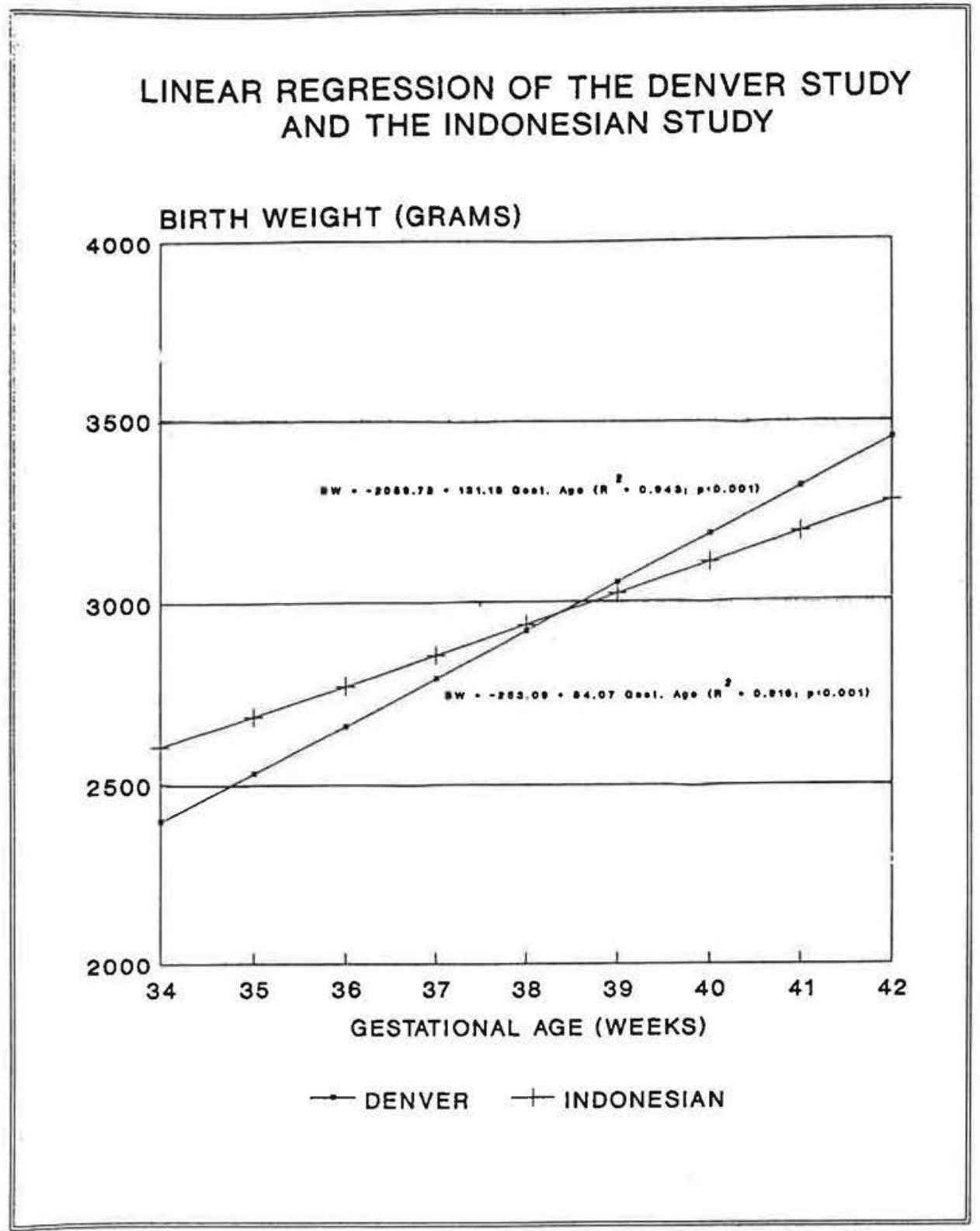

Figure 16

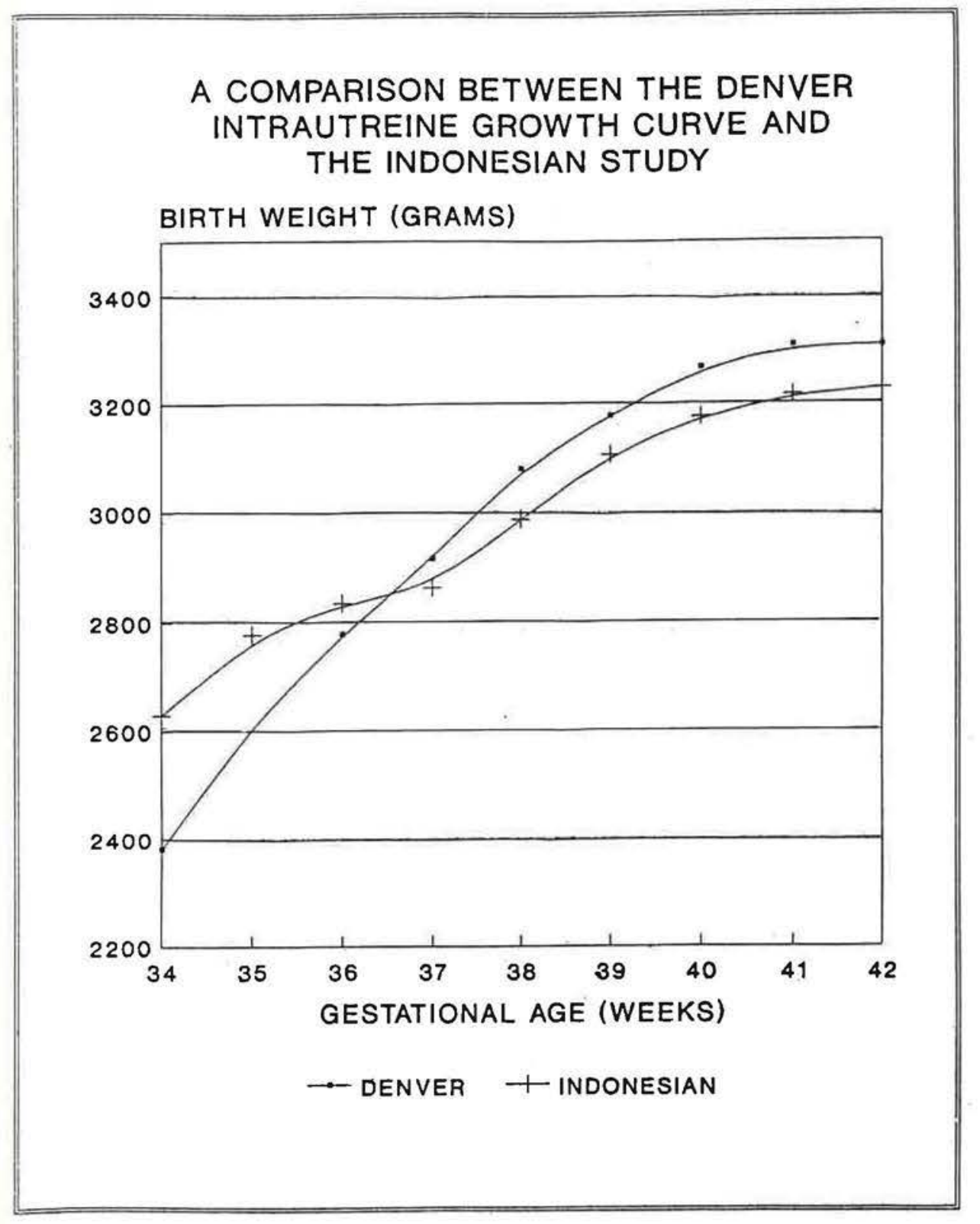

Figure 17 